\title{
A Study on Research Trends in Sandplay Therapy in Korea (2009-2018)*
}

\author{
Ahn, Soonja $^{* *}$ Lee, Yeoreum ${ }^{* * *}$ Lee, Sehwa ${ }^{* * *}$ Jang, Mikyung ${ }^{* * * *}$
}

\begin{abstract}
$<$ Abstract $>$
The aim of this study was to investigate research trends in sandplay therapy in South Korea. Thus we analyzed 205 Korean research papers published between 2009 and 2018. We grouped our results into five categories using the research trend analysis method. Those categories were research topic, subject, method, and characteristics of sandplay therapy. The results reveal the current status and limitations of sandplay research. These also suggest future research directions for sandplay therapists and researchers.
\end{abstract}

Keywords : sandplay therapy, research trends, research methods, research results

\footnotetext{
* This thesis is a modified version of a research paper presented during the 25th ISST, "Dreaming with the Hand," in Berlin, Germany.

** Main author, Ph.D. candidate in Child Counseling and Psychotherapy, Department of Child Welfare, The Graduate School of Namseoul University (hyunjuben@naver.com)

*** Corresponding author, Ph.D. candidate in Child Counseling and Psychotherapy, The Graduate School of Namseoul University (dufma91@naver.com)

***** Co-author, Ph.D. candidate in Child Counseling and Psychotherapy, The Graduate School of Namseoul University

***** Co-author, Professor, Department of Child Welfare at Namseoul University
} 
Journal of Symbols \& Sandplay Therapy, Vol.11 No.1.

\section{I . INTRODUCTION}

\section{A. Necessity and Purpose of the Research}

Sandplay therapy is a therapeutic intervention that makes use of a sand tray, sand, and figures. It is based on the World Technique developed by Margaret Lowenfeld. Later, Dora Kalff incorporated the use of sand trays into her own form of therapy, which was based on her Jungian training, and hence created what we know was "sandplay therapy" today. The sandplay therapist provides the client with a "free and protected space," in which the client creatively expresses his or her inner world using sand and figures and therefore activates self-healing. In other words, the sandplay therapist ought to be able to contain the process in which the client's unconscious becomes conscious within the therapeutic field (Jang, 2017). Here, one might ask the essential question of "why sand" among many other mediums available. Sand, the most important tool in sandplay therapy, is the prima materia. Because it is the fundamental element that exists prior to differentiation and development, it contains all possibilities (Jang, 2017). The sand tray is where the sand, the prima materia, and the water, the symbol of the unconscious, come together, thereby having the potential to heal clients' wounds at a deeper level.

Sandplay therapy can be applied to people of all ages, from children with psychological difficulties such as ADHD, selective mutism, and anxiety to adolescents, adults, and seniors (Lee - Kowen, 2016; Chung • Jang, 2016; Kim et al., 2012; Kim • Jang, 2012; Kim, 2010). It can also be used individually or in groups (Lee · Jang, 2018; Shin · Jang, 2016; Kim $\cdot$ Kim, 2015; Pak $\cdot$ Kim $\cdot$ Park, 2013; You $\cdot$ Park, 2010). Today, many studies related to sandplay therapy, including effectiveness studies and case studies, are being performed, and there are now two professional academic journals related to sandplay therapay being published in Korea.

In Korea, the first research on the trends in studies of sandplay therapy was done by Kang • Lee(2010). This study involved the analysis of 90 papers-master's theses and doctoral dissertations as well as those published in academic journals - written from 1994 to 2009 at home. Then later, Jung (2012) carried out a related study focusing on 91 master's theses and 
doctoral dissertations on sandplay therapy written from 1992 to 2011. Then there is the study of Lee - Jang (2015), which conducted a meta-analysis on the effectiveness of sandplay therapy by looking into 46 papers published between 2000 and 2014. The meta-analysis integrated the outcome of sandplay therapy programs administered to children in Korea, compared and analyzed the effect size of variables to see whether sandplay therapy can affect the treatment, and suggested that sandplay therapy is an effective technique in resolving psychological issues in children and adolescents. Because existing studies were mostly case studies, there is a need to come up with a systematic and scientific research method that would help verify the effectiveness of sandplay therapy. In addition, many of them suggested the need for an expanded participant age range (Jung, 2012; Kang $\cdot$ Lee, 2010).

Previous studies on the research trends of sandplay therapy had published for 10 years and also analyzed only around 90 papers. Moreover, the number of articles published in academic journals was only 36 , which is only a handful.

Analyzing the research trends informs of us of the current state of that specific academic field, its vision, and direction going forward (Kim • Lee 2015; Cho, 2003) Therefore, this study aims to analyze 205 articles published in domestic journals related to sandplay therapy between 2009 and 2018. It also seeks to suggest ways for sandplay therapy to advance academically by looking at the trends in sandplay therapy-related papers published for the past 10 years and exploring the direction it ought to take in the future.

\section{B. Research Questions}

1. What are the research trends of sandplay therapy papers by general facts?

2. What are the research trends of sandplay therapy papers by research subject?

3. What are the research trends of sandplay therapy papers by research participant?

4. What are the research trends of sandplay therapy papers by research methodology?

5. What are the research trends of sandplay therapy papers by intervention method and number of sessions? 
Journal of Symbols \& Sandplay Therapy, Vol.11 No.1.

\section{ПI. RESEARCH METHOD}

\section{A. Research Participants}

To observe the research trend of sandplay therapy in Korea, this study collected data by searching for papers related to sandplay therapy using the keyword "sandplay therapy" from the Research Information Service System (RISS, http://www.riss4u.net) under the Korea Education and Research Information Service (KERIS). Among them, a total of 205 papers published between 2009 and 2018 were analyzed.

\section{B. Method of Analysis for Research Trends}

The analysis framework consisted of general facts of the collected data-which includes the publication year, the journal in which the paper was published, and whether the journal was registered at KERIS - research subject, age and characteristics of research participants, research methodology, intervention method, and the number of therapy sessions. The data is treated as real numbers and shown in percentages.

\section{1) Categorization of general facts}

This study defines "general facts" as the papers' publication year, published journals, and the journal's registration status. Papers on sandplay therapy published from 2009 to 2018 were observed and classified according to journals in which they were published and the journals' registration status. The study defines "registration status" as whether a journal was registered at KERIS by 2018.

\section{2) Categorization by research subject}

To observe trends in research by their subjects, this study modified and supplemented the analysis frameworks used by Bulboltz and Williams (1999), Ki et al. (2011), and Kim and Lee (2012) so that they would be more appropriate for sandplay therapy. A total of ten items were identified: ego development, psychological/emotional, stress, communication and 
Ahn, Soonja et al. / A Study on Research Trends in Sandplay Therapy in Korea (2009-2018)

interpersonal relationship, maladaptive behavior, parent related, therapist related, diagnosed disorder related, others (symbol research), and mixed. Details are outlined in Table 1:

Table 1. Categorization by Research Subject

\begin{tabular}{ll}
\hline \multicolumn{1}{c}{ Research subject } & \multicolumn{1}{c}{ Detail } \\
\hline (1) Ego development & $\begin{array}{l}\text { Ego development and reinforcement, development of feminine and } \\
\text { masculine aspects, self-esteem, individuation process, etc. }\end{array}$ \\
\hline (2) Psychological/emotional & Anxiety, depression, aggression, internalization, externalization, etc. \\
\hline (3) Stress & Post-traumatic stress, complex trauma, parenting stress, etc. \\
\hline (4) Communication and interpersonal & Sociability, method and type of communication, relationship with the \\
\hline (5) Maladaptive behavior & opposite sex, peer relationship, etc. \\
\hline (6) Parent related & School maladjustment, social maladjustment, etc. \\
\hline (7) Therapist related & Separation, attachment, broken family, parent-child relationship, etc. \\
\hline (8) Diagnosed disorder related & Exhaustion, experiences as a therapist, etc. \\
\hline (9) Others & Diagnosed with physical and/or mental disorder \\
\hline (10) Mixed & Research subjects and symbol studies not pertaining to (1)-(8) \\
\hline
\end{tabular}

3) Categorization by research participant

After modifying and supplementing the analysis frameworks used by Buboltz (1999), Lee and Kim (2003), and Jung (2012) so that they would be more appropriate for this study, different types of research participants were categorized as follows: toddler, child, adolescent,

Table 2. Categorization by Research Participant

\begin{tabular}{ll}
\hline Research participant & \multicolumn{1}{c}{ Criteria } \\
\hline (1) Toddler & Aged 5 or below, attending daycare or kindergarten \\
\hline (2) Child & Aged from 6 to 12 , attending elementary school \\
\hline (3) Adolescent & Aged from 13 to 17 , attending middle or high school \\
\hline (4) Adult & Aged 18 or above \\
\hline (5) Senior & Aged 65 or above \\
\hline (6) Mixed & Includes two or more from (1)-(5)
\end{tabular}


Journal of Symbols \& Sandplay Therapy, Vol.11 No.1.

adult, senior, and mixed. The definition of each type is presented in Table 2:

Also, seven groups were identified based on the characteristics of research participants: individual, family, therapist, foreigner, specific job, medical diagnosis, and mixed. The criteria for categorization are exhibited in Table 3:

Table 3. Categorization by the Characteristics of Research Participants

\begin{tabular}{ll}
\hline Research participant & \multicolumn{1}{c}{ Criteria } \\
\hline (1) Individual & Participants have psychological difficulties or do not belong to (2)-(6) \\
\hline (2) Family & Participants are parents, grandparents, etc. \\
\hline (3) Therapist & Participants are therapists \\
\hline (4) Foreigner & Participants are foreigners \\
\hline (5) Specific job & Participants are engaged in a specific job, other than a therapist \\
\hline (6) Medical diagnosis & Participants are diagnosed with physical and/or mental disorder \\
\hline (7) Mixed & Participants pertain to two or more from (1)-(6) \\
\hline
\end{tabular}

\section{4) Categorization by research methodology}

Different research methodologies were categorized by revising and supplementing the method used by Kang and Lee (2011). As a result, a total of five items were identified: quantitative research, qualitative research, mixed methods research, symbol research, and others. Quantitative research refers to studies that use a statistical methodology and includes experimental research, comparative research, and correlation research. Qualitative research is used to answer questions that cannot be answered by quantitative research and includes phenomenological and hermeneutical explorations, case study, and literature review (Hwang, 2019). Mixed method research uses both quantitative and qualitative research. Symbol research analyzes the universal meaning of symbols and the symbolic expressions manifested in sandpictures.

\section{5) Intervention methods and the number of therapy sessions}

Categorization was also done according to the intervention method used and the number of sessions. There are three items under the intervention method: individual, group, 
and mixed. Individual refers to the case in which therapy was conducted on a one-on-one basis. Group is when there was one therapist dealing with two or more participants. When both methods are used for a single study, it was identified as mixed.

\section{RESEARCH FINDINGS}

\section{A. Outcome of Analysis of General Facts}

1) Number of papers published by year

From 2009 to 2018, a total of 205 papers on sandplay therapy were published in journals in Korea. Table 4 shows how many were published each year. There was a rise in the number of published papers from 2009 to 2011. But after the number peaked (32 papers, 15.61\%) in 2011, it experienced a decline from 2012 to 2018, except in 2016 when 24 papers were published.

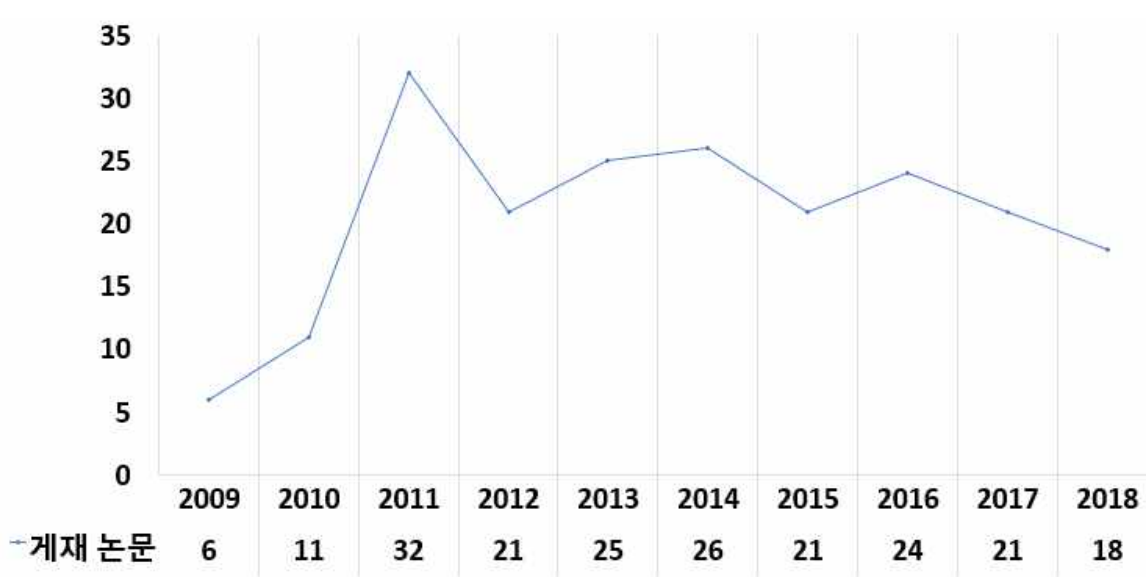

Figure 1. Number of published articles by year 
Journal of Symbols \& Sandplay Therapy, Vol.11 No.1.

Table 4. Number of Papers Published by Year

\begin{tabular}{ccc}
\hline Year & No. of papers & Percentage \\
\hline 2009 & 6 & 2.93 \\
\hline 2010 & 11 & 5.37 \\
\hline 2011 & 32 & 15.61 \\
\hline 2012 & 21 & 10.24 \\
\hline 2013 & 25 & 12.20 \\
\hline 2014 & 26 & 12.68 \\
\hline 2015 & 21 & 10.24 \\
\hline 2016 & 24 & 11.71 \\
\hline 2017 & 21 & 10.24 \\
\hline 2018 & 18 & 8.78 \\
\hline Total & 205 & 100 \\
\hline
\end{tabular}

\section{2) Trends by journals' registration status}

Trends by journals' registration status are tabulated in Table 5. According to the Korea Citation Index, there are 14 registered journals, 3 candidates journals for registration, and 14 unregistered journals as of 2019. The one with the most number of papers published is the Journal of Symbols and Sandplay Therapy, a registered journal, with 74 papers (35.92\%). This is followed by 52 papers (25.37\%) in Korean Journal of SandPlay Therapy, 9 (4.37\%) in The Journal of Play Therapy, 8 (3.88\%) in Korean Journal of Play Therapy and also Korean Journal of Child Psychotherapy, and 7 (3.40\%) in Journal of Child Welfare and Development.

Table 5. Trends by Journals' Registration Status

\begin{tabular}{cccc}
\hline Category & Title of Journal & No. of papers & Percentage \\
\hline \multirow{3}{*}{ Registered } & Family and Environment Research & 6 & 2.93 \\
\cline { 2 - 4 } & Korean Journal of Child Studies & 3 & 1.46 \\
\cline { 2 - 4 } & Family and Family Therapy & 1 & 0.49 \\
\cline { 2 - 4 } & The Journal of Play Therapy. & 9 & 4.39 \\
\hline & Pastoral Care and Counseling & 1 & 0.49 \\
\hline
\end{tabular}


Ahn, Soonja et al. / A Study on Research Trends in Sandplay Therapy in Korea (2009-2018)

Table 5. Trends by Journals' Registration Status

(Continued)

\begin{tabular}{|c|c|c|c|}
\hline Category & Title of Journal & No. of papers & Percentage \\
\hline \multirow{9}{*}{ Registered } & Journal of Symbols and Sandplay Therapy & 74 & 36.10 \\
\hline & Korean Journal of Child Studies & 5 & 2.43 \\
\hline & Journal of Parent Education & 1 & 0.49 \\
\hline & Early Childhood Education Research and Review & 1 & 0.49 \\
\hline & The Korean Journal of Rehabilitation Psychology & 2 & 0.98 \\
\hline & Journal of Youth Studies & 1 & 0.49 \\
\hline & Journal of Korean Home Management Association & 4 & 1.95 \\
\hline & Korean Journal of Christian Counseling & 2 & 0.98 \\
\hline & The Journal of the Korea Contents Association & 2 & 0.98 \\
\hline \multirow{3}{*}{ Candidate } & Journal of Child Welfare and Development & 7 & 3.41 \\
\hline & Korean Journal of Play Therapy & 8 & 3.89 \\
\hline & Korean Journal of Child Psychotherapy & 8 & 3.89 \\
\hline \multirow{15}{*}{ Unregistered } & Natural science & 1 & 0.49 \\
\hline & Korean Journal of SandPlay Therapy & 52 & 25.36 \\
\hline & Development Support Research & 1 & 0.49 \\
\hline & Journal of Social Science & 1 & 0.49 \\
\hline & Counseling and Guidance & 1 & 0.49 \\
\hline & Journal of Life-span Studies & 1 & 0.49 \\
\hline & The Study of Child-Family Therapy & 6 & 2.92 \\
\hline & Journal of Enneagram Studies & 1 & 0.49 \\
\hline & Yonsei Journal of Counseling and Coaching & 1 & 0.49 \\
\hline & Addiction and Welfare & 1 & 0.49 \\
\hline & Intelligence \& Creation & 1 & 0.49 \\
\hline & Korean Journal of Interdisciplinary Therapy & 1 & 0.49 \\
\hline & $\begin{array}{c}\text { Journal of Korea Association of } \\
\text { Parent Counseling and Play Therapy }\end{array}$ & 1 & 0.49 \\
\hline & The Hanyoung Academic Journal & 1 & 0.49 \\
\hline & Total & 205 & 100 \\
\hline
\end{tabular}


Journal of Symbols \& Sandplay Therapy, Vol.11 No.1.

\section{B. Trends by Research Subject}

Looking at the research subjects, the others (symbol research) group had the most number of papers (66 papers, 32.20\%) and therapist related had the least (2 papers, $0.98 \%)$ As for other groups, there were 43 papers (20.98\%) under mixed, 21 (10.24\%) under ego development, 16 (7.80\%) under psychological/emotional, 15 (7.32\%) under stress, 13 (6.34\%) under both maladaptive behavior and parent related and $10(4.88 \%)$ under communication and interpersonal relationship.

Table 6. Trends by Research Subject

\begin{tabular}{ccc}
\hline Research subject & No. of papers & Percentage \\
\hline Ego development & 21 & 10.24 \\
\hline Psychological/emotional & 16 & 7.80 \\
\hline Stress & 15 & 7.32 \\
\hline Communication and interpersonal relationship & 10 & 4.88 \\
\hline Maladaptive behavior & 13 & 6.34 \\
\hline Parent related & 13 & 6.34 \\
\hline Therapist related & 2 & 0.98 \\
\hline Diagnosed disorder related & 6 & 2.93 \\
\hline Others (symbol research) & 66 & 32.20 \\
\hline Mixed & 43 & 20.98 \\
\hline Total & 205 & 100 \\
\hline
\end{tabular}

\section{Trends by Research Participant}

The study also looked at the distribution of age and characteristics of participants of sandplay therapy-related researches done in Korea. First, a total of 156 papers were analyzed to see the participants' age, and the result is presented in Table 7. A total of 49 papers that 
Ahn, Soonja et al. / A Study on Research Trends in Sandplay Therapy in Korea (2009-2018)

either had no research participants as they are related to symbols and images, themes, and literature review or did not specify the age of the participants were not included in the data. Looking at the age group of the research participants, 74 papers $(47.77 \%)$ dealt with children as participants. This was followed by 46 papers (29.49\%) on adults, 23 papers (14.74\%) on adolescents, and 7 papers $(4.49 \%)$ on mixed. No research has been done on the senior group.

Table 7. Trends by the Age Group of Research Participants

\begin{tabular}{ccc}
\hline Age group & No. of papers & Percentage \\
\hline Toddler & 6 & 3.85 \\
\hline Children & 74 & 47.44 \\
\hline Adolescent & 23 & 14.74 \\
\hline Adult & 46 & 29.49 \\
\hline Senior & 0 & 0 \\
\hline Mixed & 7 & 4.49 \\
\hline Total & 156 & 100 \\
\hline
\end{tabular}

In addition, a total of 154 papers were examined to categorize the characteristics of research participants, the outcome of which is laid out in Table 8.51 papers that either had no research participants as they are related to symbols and images, themes, and literature review or did not specify the characteristics of the participants were not included in the data. More than half of them (96 papers, 62.34\%) belonged under the individual group, followed by 27 papers (17.53\%) under family related (married couples, parent-child, siblings, single-parent home, etc.), 16 (10.39\%) under foreigner related (immigrants, international students, refugees, etc.), $12(7.79 \%)$ under medical diagnosis related (psychological/emotional, physical, etc.), 2 $(1.30 \%)$ under therapist related (trainees, therapist-client, etc.), $1(0.65 \%)$ under mixed $(0.65 \%)$, and $0(0.00 \%)$ under specific job. 
Journal of Symbols \& Sandplay Therapy, Vol.11 No.1.

Table 8. Trends by the Characteristics of Research Participants

\begin{tabular}{ccc}
\hline Characteristics & No. of papers & Percentage \\
\hline Individual & 96 & 62.34 \\
\hline Family related & 27 & 17.53 \\
\hline Therapist & 2 & 1.30 \\
\hline Foreigner & 16 & 10.39 \\
\hline Specific job related & 0 & 0 \\
\hline Medical diagnosis related & 12 & 7.79 \\
\hline Mixed & 1 & 0.65 \\
\hline Total & 156 & 100 \\
\hline
\end{tabular}

\section{Trends by Research Methodology}

As for trends in research methodology, qualitative research had the highest proportion, with 89 papers (43.41\%), followed by 46 in symbol research $(22.44 \%), 41$ in quantitative research (20.00\%), 21 in mixed (10.24\%), and 8 in others (3.90\%).

Table 9. Trends by Research Methodology

\begin{tabular}{ccccc}
\hline Research methodology & No. of papers & Percentage & No. of papers & Percentage \\
\hline Quantitative & 41 & 20.00 & 14 & 28.57 \\
\hline Qualitative & 89 & 43.41 & 24 & 48.98 \\
\hline Mixed method & 21 & 10.24 & 3 & 6.12 \\
\hline Symbol & 46 & 22.44 & 1 & 2.04 \\
\hline Others & 8 & 3.90 & 7 & 14.29 \\
\hline Total & 205 & 100 & 49 & 100 \\
\hline
\end{tabular}

\section{E. Research Trends by Characteristics of Sandplay Therapy}

\section{1) Research trends by intervention method}

150 papers were processed as data, excluding 55 papers that did not deal with the 
Ahn, Soonja et al. / A Study on Research Trends in Sandplay Therapy in Korea (2009-2018)

intervention method. The result is listed in Table 10. The intervention method was divided into three categories: individual, group, and mixed (included both individual and group methods). Most of the related research used the individual method (125 papers, 83.33\%), followed by group (21 papers, 14.00\%), and mixed (4 papers, 2.67\%).

Table 10. Trends by Intervention Method

\begin{tabular}{ccc}
\hline Intervention method & No. of papers & Percentage \\
\hline Individual & 125 & 83.33 \\
\hline Group & 21 & 14.00 \\
\hline Mixed & 4 & 2.67 \\
\hline Total & 150 & 100 \\
\hline
\end{tabular}

\section{2) Research trends by the number of therapy sessions}

Excluding 58 papers that did not use any intervention methods or did not specify the number of therapy sessions, a total of 147 papers were processed as data. Research trends by the number of therapy sessions are shown in Table 11. Among the papers, 60 (40.82\%) of them conducted 21 sessions or more, followed by 33 (2.45\%) between 11 and 15 sessions, 28 (19.05\%) between 6 and 10, $12(8.16 \%)$ between 16 and 20, $8(5.44 \%)$ under five or less, and $6(4.08 \%)$ under others.

Table 11. Trends by the Number of Therapy Sessions

\begin{tabular}{ccc}
\hline No. of sessions & No. of papers & Percentage \\
\hline 5 or less & 8 & 5.44 \\
\hline $6-10$ & 28 & 19.05 \\
\hline $11-15$ & 33 & 22.45 \\
\hline $16-20$ & 12 & 8.16 \\
\hline 21 or more & 60 & 40.82 \\
\hline Others & 6 & 4.08 \\
\hline Total & 147 & 100 \\
\hline
\end{tabular}


Journal of Symbols \& Sandplay Therapy, Vol.11 No.1.

\section{CONCLUSION \& SUGGESTIONS}

The purpose of this study was to examine the trends in sandplay therapy research so as to understand where sandplay therapy stands today in academia and make recommendations for future research directions to promote its academic advancement. To this end, 205 articles published in Korean academic journals from 2009 to 2018 were collected as base data, which were categorized and analyzed by their publication year, KERIS registration status, research subject, age group and characteristics of research participants, research methodology, and the intervention method and the number of sessions. The implications of this study and recommendation for future research directions are as follows:

First, only 36 papers on sandplay therapy were published in academic journals at the time when the study of Yuri Kang and Yerang Lee was conducted in 2010. Since then, a total of 205 papers related to sandplay paper had been published during the next 10 years, with 112 in registered journals, 23 in candidate journals, and 70 in unregistered journals. It is highly significant that 205 papers were published in Korea on such a limited topic. Also, the fact that the Journal of Symbols and Sandplay Therapy, the official journal of the Korean Society of Sandplay Therapy, was selected by KERIS as a registered journal shows that studies on sandplay therapy have become ever more systematic and active.

Second, the category of research subject that had the highest number of papers was "others (symbol research)." Other categories include ego development, psychological/emotional, stress, maladaptive behavior, parent related, and so on. Since sandplay therapy is based on analytical psychology, studies on symbols ought to continue. As studies on symbols become deeper and more diverse, sandplay therapy will also deepen and advance further. It is, however, unfortunate that only a limited number of researches deal with therapists, who are one of the most important tools for therapy in sandplay. Related improvements ought to be made in the future.

Third, looking at the age distribution of research participants, an overwhelming number of studies ( 74 papers) were related to children, followed by studies on adults and adolescents. A peculiar fact is that no study has been administered to the senior group. The 
interest in senior welfare and related investments is increasing as human lifespan is getting longer and human dignity is gaining greater importance. Thus there ought to be sandplay therapy studies done on seniors going forward. Also, looking at the characteristics of research participants, it appeared that more than half the studies examined belonged under the individual group while there was none under the specific job group. Hence, sandplay therapy research ought to cover more diverse occupational groups in the future.

Fourth, in terms of the research methodology, the category that had the highest number of papers was "qualitative research," with 89 papers. This was followed by 46 papers in "symbol research," and 41 in "quantitative research." Studies on sandplay therapy are increasingly focusing on the experience of and understanding the research participants. Likewise, there is a rising number of empirical qualitative studies (Cho et al. 2015) in which the researchers play an active role as an important research tool. At the same time, however, more quantitative research ought to be conducted in the future in order to generalize the therapeutic effects of sandplay.

Fifth, looking at research trends by intervention method showed that there was the highest number of studies (125 papers) in the "individual" group. As for the number of therapy sessions, 60 studies, accounting for $40 \%$ of the total, conducted 21 sessions or more. It is recommended that future studies conduct longitudinal analysis to see the effect of sandplay therapy after quite some time had passed.

Lastly, this study referred to papers found on KERIS and RISS for data collection and thus was limited in analyzing data not listed on these websites.

The number of published papers on sandplay therapy during the recent 10 years doubles the number of those published at the time when related studies were conducted from 2009 to 2011. But as was the case 10 years ago, there still exists the need to diversify the participants. For studies on sandplay therapy to grow not only quantitatively but also qualitatively, future researches ought to be conducted on a deeper level, covering a broader range of areas. 
Journal of Symbols \& Sandplay Therapy, Vol.11 No.1.

\section{References}

An, E-S. (2014). The analytic meaning of the volcano as a symbol of the creative eruption of emotions and psychic rebirth in sandplay therapy. Journal of Symbols and Sandplay Therapy, 5(2), 77-87.

An, U-K., Kwak, H-J., Kim, J-W., \& Lim, M-H. (2017). The clinical effect of sandplay therapy on adolescent behavior and emotion-Through Minesota Multiphasic Personality Inventor. The Journal of the Korea Contents Association, 17(12), 257-265.

Ban, J-H. \& Park C-W. (2017). Cave symbols in sandplay therapy. Korean Journal of Play Therapy, 203), 235-251.

Ban, P-J. \& Woo, J-Y. (2013). An analysis of changes and themes in delinquency and aggression of children in crisis of family disorganization through sandplay therapy. The Korean Journal of Rehabilitation Psychology, 2Q1), 65-100.

Ban, P-J. \& Yoo, W-S. (2013). Analysis of changes in the behavior and themes of flight and offensive behavior of children at home dislocation crisis through sand play therapy. Rehabilitation Psychology Research, 20(1), 65-100.

Boo, J-M. (2012) Dolphin: Symbol of rebirth. Journal of Symbols and Sandplay Therapy, 3(1), $1-29$.

Boo, J-M. (2013). The sandplay therapy case of a six-year-old child with selective mutism. Journal of Child Welfare and Development, 11(2), 1-40.

Boo, J-M. (2013). A case study of sandplay therapy for a girl who witnessed domestic violence. Journal of Child Welfare and Development, 11(3), 115-152.

Boo, J-M. (2014). A case study of sandplay therapy on a child with selective mutism: A story of a life continuing over time in sandplay therapy. Journal of Symbols and Sandplay Therapy, $5(1), 45-57$.

Boo, J-M. (2014). A study of symbolic meaning of Jeju-do's front-gate Jeongnang. Journal of Symbols and Sandplay Therapy, 5(2), 11-34.

Boo, J-M. \& Kang, K-S. (2016). The phenomenological research on experiencing the stillpoint in sandplay therapy. Journal of Symbols and Sandplay Therapy, 7(1), 1-30. 
Bubolt Jr, W. C., Miller, M., \& Williams, D. J.(1999), Content analysis of research in the Journal of Counseling Psychology (1973-1998). Journal of Counseling Psychology, 464), 496.

Chae, S-Y. (2011). A case study of abused children who overcome negative paternity. Korean Journal of SandPlay Therapy, 7(3), 101-128.

Chang, H-S. (2009). A case study of sandplay therapy for an adolescent with helplessness. Intelligence \& Creation, 12, 197-235.

Chang, H-S. (2009). A case study of sandplay therapy for self-actualization of an anxious middle-aged woman with low confidence. Korean Journal of Play Therapy, 12(1), 79-102.

Chang, H-S. (2012). A study on the symbolic meaning of 'turtle' in sand play therapy. Korean Journal of SandPlay Therapy, 8(2), 29-47.

Chang, H-S. (2013). A case study of sandplay therapy for a child with microtia who is obsessed with animation characters. Korean Journal of Play Therapy, 16(1), 33-62.

Chang, H-S (2016). A case study of sandplay therapy for a delinquent adolescent who adheres excessively to his peers. Korean Journal of Play Therapy, 17(1), 95-117.

Cho, H-S. (2009). Case study based upon treatment in sand play therapy of child with Asperger Syndrome through multifaceted institute. Early Childhood Education Research and Review, 13(6), 455-480.

Cho, H-J. (2009). A case study of sandplay therapy for a child strongly adherent to a popular child. The Journal of Play Therapy, 13(3), 65-81.

Cho, H-Y., \& Kim, H-S. (2014). A case study of sandplay therapy for a child with tic disorder. The Journal of Play Therpy, 18(2), 91-107

Cho, C-S., \& Yoon, W-S. (2016). The effect of the sandplay therapy in reducing childhood encopresis symptoms. Journal of Enneagram Studies, 13(1), 49-75.

Cho, H-S., Jeong, S-W., Kim, J-S., \& Kwon, J-S. (2015). Qualitative research methodology - five approaches -. Seoul: Hakjisa.

Choi, K-R. (2018). A case study of bibliodrama in individual counseling with a Sand Play Therapy. Korean Journal of Christian Counseling, 294), 147-174.

Chung, D-U. \& Jang, M-K. (2016) (2018). Effects of sandplay therapy on parent-child communication in Chinese-Korean children experienced separation with their parents. Journal 
Journal of Symbols \& Sandplay Therapy, Vol.11 No.1.

of Symbols and Sandplay Therapy, 7(2), 29-42.

Eo, H-R. (2011). A case study of sandplay therapy for self-injured boys. Korean Journal of SandPlay Therapy, 7(1), 55-81.

Eom, M-Y. (2014). Water: A symbol of potential. Journal of Symbols and Sandplay Therapy, Q1), 59-71.

Eom, M-Y. (2012). The lotus: Rebirth of the Self. Journal of Symbols and Sandplay Therapy, 3(1), 95-107.

Esterhuyzen, A. (2014). "Safe and protected space" in sand play. Korean Journal of SandPlay Therapy, 1Q(1), 1-16.

Goh, E-K. \& Chung, K-S. (2010). A symbol of performance that overcomes relational trauma: A case of sand play therapy by a 7-year-old boy who experienced domestic violence. Korean Journal of SandPlay therapy, G(2), 1-24.

Goh, E-K. \& Chung, K-S. (2011). An analysis of the archetypical symbols of children's performance with water during sandplay therapy. Korean Journal of Child Studies, 32(3), $185-202$.

Goh, E-K. \& Chung, K-S. (2011). Symbolic meanings of space configurated by an 8 year-old Indonesian girl during sandplay therapy: Based on an analysis of Whale-Jonah complex type of fairy tales. Korean Journal of SandPlay therapy, 7(3), 1-29.

Goh, E-K. (2012). The symbolic meaning of a 10-year-old girl's birthday party food. Korean Journal of Play Therapy, $8(2), 1-19$.

Goh, E-K., Chung, K-S., \& Ryu, S-M. (2013). The symbolic meanings involved in ego-strengthening process of sandplay therapy: Focused on boys with attachment-related problem behaviors. Journal of Life-Span Studies, 3(2), 21-38.

Han, S-H. \& Kim, K-H. (2016). The effects of sandplay therapy on depression and stress from child rearing in mothers with disables children. Journal of Symbols and Sandplay Therapy, 7(2), 57-71.

Heo, M-J. (2014). Sandplay therapy case study: A child with emotional regulation problem caused by attachment trauma. Journal of Symbols and Sandplay Therapy, 5(2), 57-76.

Han, M-H. (2011). A case study of sandplay therapy for a 5-year-old child based on the 
perspectiveof ego development-Focused on sandplay themes and psychological transformation expressed in healing process. Korean Journal of SandPlay therapy, 7(1), 1-26.

Han, M-H. (2017). A study on the symbolic meanings of frogs. Korean Journal of SandPlay Therapy, 13(2), 1-18.

Han, Y-J., \& and Shin, J-W. (2009). The effect of group sand play therapy program on self-concept and self-expression of school maladjusted children. Journal of Social Science, 29, $123-137$.

Han, Y-J., Oh, S-J., \& Kim, Y-S. (2015). Development and effects of couple sandplay therapy program using the Imago method for the individual and relationship growth of premarital couples. Korean Journal of Child Psychotherapy, 10(3), 61-86.

Hong. J-Y. (1994). A study on the effect of sandplay therapy on behavioral change of attention deficit hyperactivity child. Master's thesis, Graduate School of Rehabilitation Sciences, Daegu University.

Hwang, H-G. (2017). The effect of parent group sandplay therapy on the Nepal earthquake survivors: Post-traumatic stress symptoms, parenting stress and psychological well-being of parents as well as post-traumatic stress symptoms in children. Journal of Symbols and Sandplay Therapy, $8(2)$, 57-70.

Hwang, H-J. (2019). Child research methodology. Seoul: Changjisa.

Jang, E-K. (2015). Sandplay therapy case study: A boy with difficulty in emotional regulation. Journal of Symbols and Sandplay Therapy, G(2), 13-30.

Jang, K-H. (2014). Sandplay therapy to improve self-esteem in maladjusted students. Counseling and Guidance, 49, 303-322.

Jang, M-K. (2011). The phenomenological interpretation of the Australian aboriginal dreamtime stories and their symbolism. Journal of Symbols and Sandplay Therapy, 2(2), 1-7.

Jang, M-K. (2013). Analytical psychological meaning of masks in the Hahoe Pyolshin Gut Tal (Mask) play dance in Korea. Journal of Symbols and Sandplay Therapy, 4(1), 16-20.

Jang, M-K (2014). The archetypal and psychological symbolism of masks in sandplay therapy. Journal of Symbols and Sandplay Therapy, 5(2), 1-10.

Jang, M-K. (2015). The analytic psychological meaning of Tals in Hahoe Pyolshin Gut Tal 
Journal of Symbols \& Sandplay Therapy, Vol.11 No.1.

play dance and their symbolism in sandplay therapy. Journal of Child Welfare and Development, 13(2), 99-112.

Jang, M-K. (2017). Archetypal symbolism in the recovery process from natural disaster: Sandplay therapy of Nepal earthquake adolescent survivors. Journal of Symbols and Sandplay Therapy, $8(2), 1-21$.

Jang, M-K. (2017). Analytical psychological sandplay therapy. Seoul: Hakjisa.

Jang, M-K., Choi, Y-R., Lee, S-H., Lee, Y-R., \& Cho, E-J. (2019). The effect of sandplay therapy on the PTSD symptoms and resilience of street children in Uganda. Journal of Symbols and Sandplay Therapy, 10(2), 35-50.

Jang, N-Y. (2010). The effect of sand play therapy on self-esteem and interpersonal relationship of college students with ADHD tendency. Journal of Symbols and Sandplay Therapy, 101), 61-82.

Jung, E-J. (2011). Effects of Sandplay Therapy through elementary school visits on the improvement of peer relationships and social skills of children from low-income families. Journal of Symbols and Sandplay Therapy, 2(2), 25-41.

Jeon, A-Y. (2005). A case study on sandplay therapy for a child with voice tic. The Journal of Play Therapy, $9(1), 85-102$.

Jeon, A-Y. (2009). An ethnographic case study on sandplay therapy process focusing on animal symbolism. The Journal of Play Therapy, 13(2), 45-66.

Jeon, J-H. (2018). A case study of on sandplay therapy for a children with depression and anxiety emotional problems caused by attachment. The Study of Child-Family Therapy, 16, 59-89.

Jung, B-H. (2018). The study of the image of God: focusing on Jung's the Self and Jungian sandplay therapy. The Journal of Pastoral Care and Counseling, 30, 270-304.

Jung, J-H. (2012). An Aanaysis of Research Trends in Domestic Dissertations on Sand Play Therapy - with Focus on Master's and Doctoral Dissertations in 1992 2011 -. Master's thesis, Graduate School of Social Welfare, Baekseok University.

Kang, Y-R. \& Lee, Y-R. (2010). Domestic sand play therapy research trend: focusing on sand play therapy papers $(1994 \sim 2009)$. The Study of Child -Family Therapy, 8, 79-96. 
Kang, I-A., Jang, M-K., Kim, J-K., \& Kim, M-K. (2011). The Effect of Sandplay Therapy on Depression and EEG of Parents having Children in Psychotherapy. Journal of Child Welfare and Development, 9(3), 39-60.

Kang, K-S. (2012). "A process of masculine development in a male client in his early adulthood". Journal of Symbols and Sandplay Therapy, 3(1), 49-93.

Kang, K-S. (2013). The peacock. Journal of Symbols and Sandplay Therapy, 4(1), 35-43.

Ki, Y-Y. \& Han, Y-J. (2014). The effect of communication-oriented sand play therapy program on mother-child communication and interaction, and self-efficacy and mock parenting efficacy of children. Korean Journal of Child Psychotherapy, 93), 19-46.

Ki, J-H., Lee, S-M., Kim, C-K., Jung, J-J., \& Choi, W-Y. (2011). Research trends of Korean art therapy: Focused on the thesis published in the Journal of Korean Art Therapy (1994 2010). Art Therapy Research, 18, 463-483.

Kim, D-H. (2010). A qualitative research on sand play therapy for neglected children in low-income brackets. Korean Journal of Play Therapy, 13(3), 23-38.

Kim, D-Y. (2011). A case study of sandplay therapy of a child having attachment problem. The Journal of Play Therapy, 15(2), 57-74.

Kim, E-S. (2011). Hawk. Journal of Symbols and Sandplay Therapy, 2(1), 15-28.

Kim, H-R. \& Kim, Y-J. (2015). The effect of group sand play therapy on peer attachment, impulsivity and social anxiety in smartphone-addicted adolescents. Journal of Symbols and Sandplay Therapy, G(2), 1-12.

Kim, H-J. (2011). A middle school boy who shows school maladjustment due to the loss of maternity in childhood. Korean Journal of SandPlay Therapy, 7(2), 29-57.

Kim, H-J. (2017). The symbolic meaning of the circle. Korean Journal of Sandplay Therapy, 13(1), 1-20.

Kim, H-R. (2015). A case study of a middle aged woman way to individuation - Foucused on transformation of Mandala model. Korean Journal of SandPlay Therapy, 11(2), 54-84.

Kim, H-R. \& Kim, Y-J. (2015). The effects of group sandplay therapy on peer attachment, impulsiveness, and social anxiety of adolescents addicted to smart phones. Journal of Symbols and Sandplay Therapy, Q(2), 1-12. 
Journal of Symbols \& Sandplay Therapy, Vol.11 No.1.

Kim, H-S. (2018). The symbol of bear. Korean Journal of SandPlay Therapy, 14(1), 1-15.

Kim, H-Y. (2016). A case study of sandplay therapy with a middle-aged woman having difficulty in relationships. Journal of Child Welfare and Development, 14(1), 39-56.

Kim, J-A. (2015). The effect of school counseling using sandplay therapy on the emotional or behavioral problems of adolescents. Korean Journal of SandPlay Therapy, 11(2), 28-51.

Kim, J-K. (2013). A study on the symbol of white tiger in a dream. Korean Journal of SandPlay Therapy, 9(2), 31-49.

Kim, K-E. (2017). A case study on sandplay therapy of a girl strengthening her ego. Korean Journal of SandPlay Therapy, 13(2), 1-29.

Kim, K-N. (2011). Chan's sandplay story: Healing and development in a nine-year-old boy. Journal of Symbols and Sandplay Therapy, 2(1), 29-53.

Kim, K-N. (2012). A well. Journal of Symbols and Sandplay Therapy, 3(2), 55-72.

Kim, K-N. (2017). The symbol of integration of the opposite poles experienced in the process of individuation: Mother. Journal of Symbols and Sandplay Therapy, \&(2), 41-56.

Kim, K-H. (2013). Analysis of the subject of hero mythology in the sand tray. Korean Journal of SandPlay Therapy, $9(1), 41-65$.

Kim, K-W. (2011). Value of using symbolic figures in psychotherapy. Journal of Symbols and Sandplay Therapy, 2(1), 1-14.

Kim, K-R. \& Han, Y-J. (2012). The effects of structured group sandplay therapy program for children's self-perception and ego-resilience. Korean Journal of Child Psychotherapy, 71), 27-48.

Kim, M-K., Lee, M-S., Jang, M-K., \& Kim, J-K. (2011). The effect of sandplay therapy on the changes of brain waves and reduction of anger of the female victims of family violence. Journal of Child Welfare and Development, 9(3), 1-18.

Kim, M-K. (2015). A study on the symbol of 'toad' in sandplay therapy. Korean Journal of SandPlay Therapy, 11(2), 6-25.

Kim, S-S. \& Kim, K-H. (2016). Analysis of the wounding-healing themes in sandplay therapy process for children with emotional instability and attention deficit children. Family and Environment Research, 54(6), 631-642.

Kim, S-R. (2012). A case study on the sandplay therapy in woman victims of domestic 
violence from the perspective of alchemy and 'hairy princess'. Korean Journal of SandPlay Therapy, $8(1), 21-41$.

Kim, S-Y. \& Kim, J-H. (2013). A case study on long-term sand play therapy for a child with oppositional defiant disorder. The Korean Journal of Rehabilitation Psychology, 2033), 427-462.

Kim, S-O. (2010). Mourning through sandplay therapy for a 10-year-old girl who witnessed her mother's suicide. Korean Journal of SandPlay Therapy, Q(2), 25-65.

Kim, S-O. \& Lee, E-C. (2011). A study on the effects of sandplay on children's self-esteem and sociality. Korean Journal of SandPlay Therapy, 7(4), 57-79.

Kim, S-W. \& Sim, H-O. (2018). A case study of sandplay therapy for a boy in an elementary school with social and emotional difficulties. Family and Environment Research, 56(6), 589-601.

Kim, S-O. (2014). The effects of sandplay therapy on imroving the self-differentiation, depression, and mother-child relationship of mothers with teenage children. Journal of Symbols and Sandplay Therapy, 5(1), 1-12.

Kim, S-S. (2018). Comparative analysis in the use of sandtray therapy symbols by the age of the client and general children. Journal of Sandtray Therapy, $8(1), 60-81$.

Kim, S-Y. (2016). Incorporating sandplay therapy in family therapy: A case study. Family and Family Therapy, 24(1), 73-99.

Kim, S-Y., Jang, M-K. (2012). The effects of sandpaly therapy on the stress and stress-related EEG values of parents of children who visited counseling institutes. Journal of Symbols and Sandplay Therapy, 3(2), 25-36.

Kim, T-Y. (2010). The effect of sandplay therapy on ADHD adults' depression and anxiety. Journal of Symbols and Sandplay Therapy, 1(1), 15-40.

Kim, T-G. (2010). Butterfly: Symbol of individuation. Journal of Symbols and Sandplay Therapy, $1(1), 1-13$.

Kim, Y-M., Jang, M-K., Kim, M-K., \& Kim, J-K. (2012). The effects of sandplay therapy on parenting stress and saliva cortisol levels of parents undergoing child counseling programs. Korean Journal of Child Studies. 33(3), 83-97.

Kim, Y-R. (2011). The cave: A channel for journeying toward ego development. Journal of 
Journal of Symbols \& Sandplay Therapy, Vol.11 No.1.

Symbols and Sandplay Therapy, 22), 43-53.

Kim, Y-R. (2013). The lighthouse: A guide for the journey. Journal of Symbols and Sandplay Therapy, 4(2), 65-69.

Kim, Y-S. (2018). Comparison of story expressions and symbolic expressions of sandplay therapy between Korean Chinese parents and children both separated and living together. Journal of Symbols and Sandplay Therapy, 911$), 1-15$.

Koo, S-K. (2018). Qualitative research on educational analysis experiences of sandplay counselors. The Study of Child-Family Therapy, 16, 1-24.

Koo, S-K. \& Han, Y-J. (2018). A case study of sandplay therapy through which a child's mother integrates the shadow as part of her personality. The Journal of Play Therapy, 22(3), $87-104$.

Kowen, M-R. (2015). The transformational symbolism of skeleton as a meaning of rebirth. Journal of Symbols and Sandplay Therapy, Q(1), 1-20.

Kowen, M-R. (2017). A 10-year-old girl`s overcoming the negative mother complex and its relationship to ego development. Journal of Symbols and Sandplay Therapy, \&(1), 1-32.

Kwon, M-S. (2010). A review of the common meaning of sand play therapy for children with mother and child deficiency, self-esteem, and interaction changes. Korean Journal of Interdisciplinary Therapy, 2(2), 49-71.

Kwak, H-J. (2014). A topographical comparison between location of village Dangsan Tree in Korean shamanism with sandtray map. Korean Journal of SandPlay Therapy, 102), 33-47.

Kwak, H-J. (2014). A case study of a middle-aged woman in PTSD due to father's death. Korean Journal of SandPlay Therapy, 101), 109-152.

Kwak, H-J. (2017). The clinical effect of school sand play group counseling on child emotion and behavior. The Journal of Korea Contents Association, 18(12). 54-61.

Kwak, S-K., \& Seo, M-A. (2018). The effect of client-centered sandplay therapy on the depression, aggression and ego development stage of children in a community child center. Journal of Symbols and Sandplay Therapy, 92), 1-22.

Kwon, M-S. (2010). The study of the common significance and the process of a change in self-esteem and interaction that is shown in the sand-play therapy when the attachment- 
Ahn, Soonja et al. / A Study on Research Trends in Sandplay Therapy in Korea (2009-2018)

deficient children with mother. Korean Journal of Interdisciplinary Therapy, 2(2), 49-71.

Lee, A-S. (1986). Trend analysis of thesis for early childhood education (1982 1985). Master's Thesis, Graduate School, Ewha Womans University.

Lee, B-Y. \& Jang, M-K. (2015). Comparisons between North Korean adolescent defectors and South Korean adolescents in representations in sandplay therapy. Journal of Symbols and Sandplay Therapy, G(2), 31-45.

Lee, B-Y. \& Jang, M-K. (2015). Effects of communication-focused sand play therapy on mother-child communications and interactions, child self-efficacy, and maternal parenting efficacy. Journal of Child Welfare and Development, 13(4), 61-72.

Lee, E-C. (2016). A case study on the sandplay therapy for an adolescent who underwent complex posttraumatic stress disorder. Korean Journal of SandPlay Therapy, 1967(2), 1-26.

Lee, E-C. \& Kim, S-H. (2011). A study on gender difference in children's self-development stage through sandplay. Korean Journal of SandPlay Therapy, 7(4), 23-56.

Lee, E-H. (2012). The effect of the sand play therapy impacted on the society of children in low-income homes. The Hanyoung Academic Journal, 4, 149-176.

Lee, H-J. (2017) A study on the symbolism of elephants in sandplay. Korean Journal of SandPlay Therapy, 13(2), 1-19.

Lee, H-J. (2018). A case study of art therapy combined with sandplay therapy for anger and emotion control of adolescent. Addiction and Welfare, 2(1), 103-124.

Lee, H-R. (2012). A case study of sandplay therapy for "Puer Aeternus". Korean Journal of Play Therapy, 15(3). 391-418.

Lee, J-E., Park, J-Y., \& Park, B-J. (2013). The effect of sandplay therapy for couples on college students' self-differentiation and heterosexual relationship satisfaction. Journal of Korean Home Management Association, 31(6), 97-112.

Lee, J-H. \& Kowen, M-R. (2016). The effects of sandplay therapy on anxiety and defense style of mother of disabled children. Journal of Symbols and Sandplay Therapy, 7(1), 65-80.

Lee, J-S. \& Jang, D-H. (2015). A meta-analysis on the efficacy of sandplay therapy. Korean Journal of Child Psychotherapy, 1Q1), 1-26.

Lee, M-A. (2010). Coming of age: Sandplay therapy of an anxious youth. Journal of Symbols and 
Journal of Symbols \& Sandplay Therapy, Vol.11 No.1.

Sandplay Therapy, 1(1), 41-60.

Lee, M-A. (2013). The dragon: The principle of cosmos. Journal of Symbols and Sandplay Therapy, $4(2), 70-76$.

Lee, M-A. \& Suh, H-J. (2016). A study of sand play therapy for children exposed to the sex by their parents - focusing on self-esteem and sociality. Journal of Parent Education, \&(2), 91-110.

Lee, M-S. (2011). Children's sand play therapy tends to use props (symbols) by address. Child and Family Therapy Research, 9, 54-66.

Lee, M-S. \& Park, B-J. (2011). Children's use of symbols by age and gender in sand play pictures. The Journal of Play Therapy, 15(1), 29-42.

Lee, M-Y. (2011). Food as a symbol. Journal of Symbols and Sandplay Therapy, 2(2), 9-23.

Lee, M-Y. (2012). The sword: The development of consciousness. Journal of Symbols and Sandplay Therapy, 3(2), 37-53.

Lee, N-K. (2016). Candlelight: Symbol of consciousness in holy protective space. Journal of Symbols and Sandplay Therapy, 7(2), 73-88.

Lee, N-K. (2015). Mountain: Maternal symbolism of conceiving individuation. Journal of Symbols and Sandplay Therapy, Q(1), 63-78.

Lee, P-S. \& Lee, M-S. (2011). A case study of a 6-year-old child who is experiencing maternal separation anxiety before entering elementary school. Korean Journal of SandPlay Therapy, $7(3), 67-99$.

Lee, P-S. (2013). Dragon symbol in Korean culture. Korean Journal of SandPlay Therapy, 9(2). $51-65$.

Lee, P-S (2014). Sandplay therapy of the abused child - A case about self reinforcement to become a girl heroine. Korean Journal of SandPlay Therapy, 102), 117-142.

Lee, S-C. (2017). A case study of sandplay therapy on a 5-year-old boy for the birth of his ego. Korean Journal of SandPlay Therapy, 13(2), 1-28.

Lee, S-H. \& Shahi, P. (2016), Image experiences in sandplay therapy in adolescents living in welfare facilities who suffered Nepal earthquake. Journal of Symbols and Sandplay Therapy, $7(1), 81-96$. 
Ahn, Soonja et al. / A Study on Research Trends in Sandplay Therapy in Korea (2009-2018)

Lee, S-H. \& Jang, M-K. (2018). A study of themes and symbols in group sandplay therapy of Rohingya refugee children in Malaysia. Journal of Symbols and Sandplay Therapy, (1), 53-70.

Lee, S-H. (2016). A case study of the sand play therapy based on identity based metacognition model, The Journal of Play Therapy, 2033), 93-116

Lee, S-H. \& Yoon, H-Y. (2012). A study on the effects of sandplay therapy on the psychological well-being of undergraduates. Journal of Symbols and Sandplay Therapy, 3(2), $1-23$.

Lee, S-H. (2014). The mouse and the cat: Inevitable opposites of the shadow. Journal of Symbols and Sandplay Therapy, 5(2), 33-56.

Lee, S-H. \& Jang, M-K. (2018) A study of themes and symbols in group sandplay therapy of Rohingya Refugee children in Malaysia. Journal of Symbols and Sandplay Therapy, 91), 53-70.

Lee, S-M. \& Jang, M-K. (2013). Effects of sandplay therapy on the emotional clarity and brain indexes related to self-regulation of female delinquent juveniles. Journal of Symbols and Sandplay Therapy, 4(1), 1-8.

Lee, S-Y. \& Kim, S-H. (2013). A content analysis of Christian counseling research. Counseling Research, 4(2), 295-307.

Lee, Y-J. \& Jang, M-K. (2012). The effects of sandplay therapy on the depression, anxiety and saliva cortisol of university students with ADHD tendencies. Journal of Symbols and Sandplay Therapy, 3(1), 31-47.

Lee, Y-J. (2013). A study of the sandplay therapy case of a 9-year-old girl seen from Mahler`s ego developmental viewpoint. Journal of Symbols and Sandplay Therapy, 4(1), 21-34.

Lee, Y-R. \& Chun, Y-S. (2017). Symbols and themes in sandplay therapy for Korean-Chinese adolescent from broken families in China. Journal of Symbols and Sandplay Therapy, $8(1)$, 67-80.

Lee, Y-R., Jang, M-K., \& Shim, J-H. (2018). The effectiveness of group sandplay therapy on quality of peer relationship and behavioral problems of Korean-Chinese in China. Journal of Symbols and Sandplay Therapy, 92), 61-80.

Lee, Y-S. (2016). A case study on the sandplay therapy in which a middle-age man conducted an initiation. Korean Journal of SandPlay Therapy, 1967(2), 1-29. 
Journal of Symbols \& Sandplay Therapy, Vol.11 No.1.

Lee, Y-S. (2017). Death: Symbol of threshold of spiritual rebirth. Journal of Symbols and Sandplay Threapy, $8(1)$, 49-65.

Lee, Y-R. (2018). Symbolism of mirrors as the first step of individuation and self-awareness. Journal of Symbols and Sandplay Therapy, (1), 39-52.

Lee, Y-J. (2015). A case study of sandplay therapy with a 7-year-old boy with problems of aggression based on object relation theory. Korean Journal of Child Psychotherapy, 102), $15-37$.

Lim, M-J. (2011). A case study on the sandplay therapy of a child with depressive tendencies. Korean Journal of SandPlay Therapy, 7(3), 31-65.

Lim, Y-S. (2016). A case study of sand play therapy for an adult male university student diagnosed with epilepsy. The Study of Child-Family Therapy Research, 14(2), 81-98.

Maeng, J-Y, \& Jang, M-K. (2014). The effects of sandplay therapy on the anxiety, self-esteem, and sociality of college students with blindness. Journal of Symbols and Sandplay Therapy, 5(1), $27-44$.

Masayo, C. (2011). Structural and therapeutic intervention in the psychological world seen in the sandbox. Korean Journal of SandPlay Therapy, 7(4), 81-108.

Moon, S-Y. (2016). A case study on the sandplay therapy to a woman in her 20s with complex PTSD. Korean Journal of SandPlay Therapy, 1967(2), 1-38.

Na, K-H. \& Jang, M-K. (2017). The effects of sandplay therapy on internalized shame and self-expression of children of alcoholics. Journal of Symbols and Sandplay Therapy, 8(1), 33-48.

Noh, M-J. (2018). A case study on the sandplay therapy regarding the conscientization process of the masculinity of a middle-aged woman having difficulties with interpersonal relationships. Korean Journal of SandPlay Therapy, 14(1), 1-34.

No, S-H. \& Kim, M-K. (2013). The effects of sandplay therapy on anxiety, interpersonal stress, and salivary cortisol levels of university students with ADHD tendencies. Journal of Symbols and Sandplay Therapy, 4(1), 9-15.

Oh, K-I. \& Kim, D-Y. (2017). The case study of the sandplay therapy for the depressed adolescent. Development Support Research, Q1), 55-67.

Oh, M-H. \& Park, S-O. (2014). The effect of group sand play therapy on emotional expression 
and interpersonal relations in schizophrenia patients. Natural Science, 25, 145-173.

Oh, S-S. (2013). Verification of the effect of couples' sand play therapy on the improvement of marital relationship. Korean Journal of SandPlay Therapy, 9(2), 1-29.

Oh, S-H. (2011). The effect of sandplay therapy on Chinese students in Korea with loneliness, anxiety and school adaptation. Journal of Symbols and Sandplay Therapy, 2(1), 55-75.

Oh, A-N., You, S-E., \& Park, B-J. (2013). The effect of sandplay therapy with parent-children on mother-child's attachment security and communication. Korean Journal of Child Studies, 34(6), 31-55.

Ok, S-J. \& Roh, N-S. (2017). The effect of couples sandplay therapy on the relationship of children with ADHD and sibling. Korean Journal of Christian Counseling, 28(3), 85-112.

Park, M-H. \& Lee, M-Y. (2013). The effects of sandplay therapy on visually disabled university students' anxiety, depression, and psychological well-being. Journal of Symbols and Sandplay Therapy, 4(2), 51-59.

Park, A-K. (2016). A case study of sandplay therapy for a male adolescent with trauma of incest sexual assault. Journal of Symbols and Sandplay Therapy, 7(2), 1-28.

Park, J-M 2018). A study on the images used in sandplay therapy by children who experienced the Geyeongju earthquake. Journal of Symbols and Sandplay Therapy, 92), 31-45.

Park, S-Y. (2016). A study on the symbolic meaning of bridges in sandplay therapy. Korean Journal of SandPlay Therapy, 1967(2), 1-15

Park, S-Y. (2017). A case study on the sandplay therapy for an initiation of an adolescent boy. Korean Journal of SandPlay therapy, 13(1), 1-25

Park, B-J. (2014). The Symbolic Meaning of the Tree in Korean Traditional Faith and Rituals. Korean Journal of SandPlay Therapy, 101), 79-94.

Park, S-M. \& Kim, D-I. (2011). A case study of sandplay therapy on a mid-aged woman who recovers her true female identity. Korean Journal of Child Psychotherapy, G(2), 1893-1914.

Park, S-K., Kim, H-W., \& Park, B-J. (2013). The Effect of Group Sandplay Therapy on Self-expression and School Adjustment of School Violence Victims. Korean Journal of Youth Studies, 20(8), 175-202.

Park, A-K. (2015). The cat: A symbol of femininity. Symbols and Sandplay Therapy, Q1), 37-53. 
Journal of Symbols \& Sandplay Therapy, Vol.11 No.1.

Park, J-O. (2014). A study on the symbols of rats. Korean Journal of SandPlay Therapy, 10(2), $49-68$.

Park, J-H. (2012). A study on the individuation process of a middle-aged woman who immigrated to the United States. Korean Journal of SandPlay Therapy, 8(1), 43-71.

Park, J-Y. \& Park, B-J. (2011). The effect of group sand play therapy on children's social anxiety. Korean Journal of SandPlay Therapy, 7(4). 1-22.

Park, J-Y. \& Park, B-J. (2012). A case study on group sand therapy in children with weak ego strength. Child and Family Therapy Research, 10, 35-52.

Park, H-J. \& Han, Y-J. (2011). A study on the symbols of water from analytical psychological perspective. Korean Journal of SandPlay Therapy, 7(2), 59-72.

Park, H-Y. (2015). A study on the effect of sand play therapy on unstable attachment type children. Yonsei Counseling Coaching Research, 3, 87-110.

Park, H-Y. (2015). A study on effects of sand play therapy for insecurely attached children. Yonsei Journal of Counseling and Coaching, 3, 87-110.

Ryu, H-J. (2012). The little mermaid: Development of the conscious feminine. Journal of Symbols and Sandplay Therapy, 3(2), 73-89.

Sim, E-Y. \& Jang, M-K. (2013). Effects of sandplay therapy on aggression and brain waves of female juvenile delinquents. Journal of Symbols and Sandplay Therapy, 4(2), 45-50.

Sim, H-O. (2016). Case study of sandplay therapy with a 6 year old girl suffering from alopecia areata. Korean Jouranl of Play Therapy. 19(1), 1-19

Sim, H-O. (2016). A case study of sandplay therapy for a boy from a grandparentsgrandchildren family experiencing difficulties in school work: A focus on alchemical viewpoints. Korean Jouranl of Play Therapy. 1944), 423-446.

Shin, J-W. \& Jang, M-K. (2016). Effect of group sandplay therapy to be addicted youth's addiction levels and anxiety. Journal of Symbols and Sandplay Therapy, 7(1), 31-45.

Shin, Y-S. (2017). A study on the symbolic meaning of deer in sandplay. Korean Journal of SandPlay Therapy, 13(2), 1-25.

Seo, S-H. (2013). A case study of sand play therapy for an 8-year-old child with tendency to depression, anxiety, and externalization. Korean Journal of SandPlay Therapy, 91), 1-39. 
Sung, E-K. (2015). Tears: Symbol of healing towards the individuation. Journal of Symbols and Sandplay Therapy, Q(2), 47-60.

So, B-H. (2018). The staff as a symbol of spiritual guidance for individuation. Journal of Symbols and Sandplay Therapy, 9(2), 43-59.

Shin, M-K. (2011). Individual sand play therapy case of mother and daughter with high anxiety level. Korean Journal of SandPlay Therapy, 7(2), 1-27.

Sim, H-O. (2011). A case study of a 5th grade girl from a divorced family recovering femininity through the sandplay therapy. Family and Environment Research, 491), 55-65.

Sim, H-O. (2011). A case study on the process in which a facility child with difficult behavior regulation becomes conscious through sand play therapy. Play Therapy Research, 15(3), $101-116$

Sim, H-O. (2011). A study of the consciousness process of an institutionalized child showing the problems of regulating behaviors through sandplay therapy. The Journal of Play Therapy, 15(3), 101-116.

Sim, H-O. (2012). A case study on sandplay therapy for a girl suffering from selective mutism. Korean Journal of Child Studies. 33(1), 41-62.

Sim, H-O. (2012). A case study of sandplay therapy for a boy from grandparents-grandchildren families showing internal and external behavioral problems. Korean Journal of Child Psychotherapy, 7(2), 75-96.

Sim, H-O. (2013). A case study of sandplay therapy for a boy from a low-income family having passive aggression problems. Korean Journal of Child Psychotherapy, \&(2), 1-22.

Sim, H-O. (2014). A case study of sandplay therapy from the perspective of the father complex for a female college student raised in a wife-battering family. Journal of Korean Home Management Association, 32(2), 143-157.

Sim, H-O. (2014). A case study of sandplay therapy for a middle school-aged boy having severe conflicts with his mother - Focused on initiation. Journal of Korean Home Management Association, 32(6), 1-18.

Sim, H-O. (2014). A case study of sandplay therapy for an elementary school boy living in a small income fatherless family who exhibits mal adjustments in both school and home. 
Journal of Symbols \& Sandplay Therapy, Vol.11 No.1.

Korean Journal of Child Studies, 35(1), 17-41.

Sim, H-O. (2015). A case study of sandplay therapy for an elementary school-aged girl living in a home suffering from severe conflicts between her mother and older brother: A focus on fairy tales. Korean Journal of Child Studies, 36(1), 19-45.

Sim, H-O. (2015). The process of understanding the psyche of an elementary school-aged boy who is mentally handicapped through sandplay therapy. Korean Nursery School Conference, $2015,257-258$

Sim, H-O. (2017). A case study of sandplay therapy with a middle-aged woman having difficulty in relationships. Family and Environment Research, 55(3), 303-319.

Sim, H-O. (2018). A case study of sandplay therapy for a woman with a negative mother complex who wants to be free from family. Family and Environment Research, 56(4), $331-354$

Shin, Y-S. (2017). A study on the symbol of 'deer' in sandplay therapy. Korean Journal of SandPlay Therapy, 13(2), 1-25.

Thapa, S. \& Jang, M-K. (2016). The Hindu Gods, snakes and fairies Images in the sandplay therapy process of the Nepalese earthquake survivors. Journal of Symbols and Sandplay Therapy, 7(2), 43-55.

Wang, Y. \& Jang, M-K. (2013). Symbolic icons used by Han Chinese and Tibetan people appearing in sandplay scenes their religious/cultural symbolism. Journal of Symbols and Sandplay Therapy, 4(2), 60-64.

Wee, Y-H. (2015). A case study on sandplay therapy for a middle-aged woman suffering from hatred of her mother. Korean Journal of SandPlay Therapy, 11(2), 88-124.

Woo, H-J. (2010). A case study of sandplay therapy in a college student with symptoms of post-traumatic stress disorder. Family and Environment Research, 48(3), 55-69.

Woo, H-J. (2012). A case study of sandplay therapy in a child with anxiety. Journal of Korea Association of Parent Counseling and Play Therapy, 3(3), 23-43.

Yoo, M-R. (2014). A study on the case of sand play therapy for a 30-year-old female working to restore maternity. Korean Journal of SandPlay Therapy, 102), 69-98.

Yoo, S-Y. (2016). Millstone: The creation of a new coalescence consciousness of opposites. 
Journal of Symbols and Sandplay Therapy, 7(1), 47-64.

Yoo, S-Y. (2015). The effect of sandplay therapy on the anxiety, attachment relations, and interpersonal stress of children of alcoholic fathers. Journal of Symbols and Sandplay Therapy, Q1), 21-35.

You, S-E. \& Park, B-J. (2010). The effect of group sandplay therapy for children's anxiety decrease and ego-resilience promotion. The Journal of Play Therapy, 14(1), 67-88.

You, S-E. \& Park, B-J. (2011). The effect of group sandplay therapy for children's self-concept construction and ego-development enhancement. Korean Journal of Child Studies, 32(3), $163-184$.

Yoo, S-E. \& Park, B-J. (2015). The effect of family sand play therapy using structural family therapy on the health of emotional behavioral disabilities family. Journal of the Korean Home Management Association, 33(4), 33-50.

Yoon, B-N. (2014). A study on the symbol 'Butterfly'. Korean Journal of SandPlay Therapy, 10(2), 99-115.

Yang, Y-S. (2014). The effects of sandplay therapy on the behavioral problems, self-esteem, and emotional intelligence of children in grandparents-grandchildren families in rural Korean areas. Journal of Symbols and Sandplay Therapy, 5(1), 13-25.

Yoo, S-Y. (2015). The effect of sandplay therapy on anxiety, attachment relation, and interpersonal stress of children with alcoholic fathers. Journal of Symbols and Sandplay Therapy, Q1), 21-35.

Yun, M-Y. (2017). A case study on the sandplay therapy for the ego development and ego identity formation process of a school-refusing adolescent who exhibits complex trauma. Korean Journal of SandPlay Therapy, 13(1), 1-37.

Yang, H-Y. (2012). An example of sand play therapy for the emotional support of alcoholic children. Korean Journal of SandPlay Therapy, $8(2), 49-68$.

Yeo, N-J (1997). The effect of verbal therapy in children with selective impotence using sandbox play. Master's thesis, Yeungnam University Graduate School of Education. 

상징과모래놀이치료, 제 11 권 제 1 호

Journal of Symbols \& Sandplay Therapy

2020, 6, Vol. 11, No. 1, 73-97.

doi https://doi.org/10.12964/jsst.20002

\title{
국내 모래놀이치료 연구동향(2009-2018)*
}

\section{A Study on Research Trends in Sandplay Therapy in Korea (2009-2018)}

\author{
안 순 자 ${ }^{* *}$ \\ 이 여 름 ${ }^{* * *}$ \\ 이 세 화 ${ }^{* * *}$ \\ 장 미 경*** \\ Ahn, Soonja \\ Lee, Yeoreum \\ Lee, Sehwa \\ Jang, Mikyung
}

\begin{abstract}
$<$ Abstract $>$
The aim of this study was to investigate research trends in sandplay therapy in South Korea. Thus we analyzed 205 Korean research papers published between 2009 and 2018. We grouped our results into five categories using the research trend analysis method. Those categories were research topic, subject, method, and characteristics of sandplay therapy. The results reveal the current status and limitations of sandplay research. These also suggest future research directions for sandplay therapists and researchers.
\end{abstract}

Keywords : sandplay therapy, research trend, research method, research result

* 본 논문은 독일 베를린에서 열림 국제모래놀이치료학회(ISST) 제25회 학술대회 'Dreaming with the Hand'에서 연구발표된 것을 수정·보완하였음.

** 주저자, 남서울대학교 아동복지학과 대학원 박사과정 수료 (hyunjuben@naver.com)

**** 교신저자, 남서울대학교 아동복지학과 대학원 박사과정 수료 (dufma91@naver.com)

**** 공동저자, 남서울대학교 아동복지학과 대학원 박사과정 수료

****** 공동저자, 남서울대학교 아동복지학과 교수 
Journal of Symbols \& Sandplay Therapy, Vol.11 No.1.

\section{I. 서 론}

\section{1. 연구의 필요성 및 목적}

모래놀이치료는 모래, 피겨, 모래상자 등을 이용한 심리치료로 Lowenfeld의 세계기법(World Technique)을 적용하여 시작되었다. 이후 Dora Kalff가 Jung이론에 기초한 모래놀이치료를 발 전시켰다. 모래놀이치료자는 내담자에게 '자유롭고 보호받는 공간'을 제공하며 내담자가 자 신의 내면세계를 모래와 피겨를 이용하여 창조적으로 표현하며 자기 치유력을 기를 수 있 게 한다. 즉 치료적 장을 통해 모래놀이치료자는 내담자가 자신의 무의식을 의식화하는 것 을 담아줄 수 있어야 한다(장미경, 2017). 그렇다면 다른 매체 중 왜 모래인가에 대한 본질 적인 질문을 가질 수 있다. 모래놀이치료에서 가장 중요한 도구인 모래는 지구의 원질료 (prima materia)로 분화하고 발달하기 이전의 본질적 요소이기 때문에 모든 가능성을 가지고 있으며(장미경, 2017) 모래상자는 이러한 원질료인 모래와 무의식의 상징인 물의 만남으로 내담자의 보다 깊은 상처를 치유할 수 있는 가능성을 가지고 있다.

모래놀이치료는 $\mathrm{ADHD}$, 선택적 함구증, 불안 등의 심리적 어려움을 가진 아동뿐만 아니 라 청소년, 성인, 노인까지 모든 연령에게 적용할 수 있는 심리치료기법(이진희-권미라, 2016; 정다운·장미경, 2016; 김영미 외, 2012; 김선영·장미경, 2012; 김태영, 2010)이며, 집 단으로도 적용할 수 있다(이여름·장미경 - 심종희; 2018; 신지환 · 장미경, 2016; 김혜림·김 유진, 2015; 박슬기·김효원 · 박부진, 2013; 유승은 - 박부진, 2010). 모래놀이치료 관련 효 과성 연구, 사례연구 등 다양한 관련 연구가 활발히 진행되고 전문학회지도 2 곳에서 출판 되고 있다.

국내 모래놀이치료 연구동향은 강유리 - 이여랑(2010)에 발표한 연구로 시작되었다. 강유 리 - 이여랑(2010)은 1994년부터 2009년까지의 모래놀이치료 관련 석박사 학위논문과 학회지 논문 90편을 분석하였다. 이후 정진호(2012)가 1992년부터 2011년까지의 석박사 학위논문을 중심으로 91편의 모래놀이치료 관련 연구들을 수집하여 분석하였다. 이정숙-장대형(2015) 은 2000년부터 2014년에 발행된 46편의 연구에서 모래놀이치료의 효과성에 대한 메타분석 을 진행하였다. 이 연구는 메타분석을 통하여, 한국의 아동을 대상으로 실시된 모래놀이치 료 프로그램의 효과에 대한 결과들을 통합하고 치료 효과에 영향을 미칠 수 있는가에 대한 변인들의 효과크기를 비교·분석하여 모래놀이치료가 아동 및 청소년의 심리적 문제를 해 결하는데 효과적인 심리치료 기법임을 제시하였다. 즉 선행연구에 따르면 모래놀이치료 연 구는 주로 사례연구가 차지하여 모래놀이치료를 효과를 검증할 수 있는 체계적이고 과학적 연구방법이 강구될 필요성이 있었으며 보다 다양한 연령층으로 연구대상으로 확장 할 필요 가 있다고 제안하였다(정진호. 2012; 강유리·이여랑, 2010). 
그러나 모래놀이치료 연구동향 선행연구들은 이미 10 년 동안 출판된 것이며, 약 90 여편 의 논문만이 분석되었다. 또한 당시 학술지 논문은 36 편으로 10 년 동안 출판된 모래놀이치 료의 학술지 논문이 매우 적은 수였다.

이러한 연구동향을 분석하는 것은 그 학문의 현 상태나 추구하는 목적, 앞으로의 방향 등을 알아볼 수 있다(김경숙-이상은, 2016; 조성호, 2003). 따라서 본 연구에서는 2009년부 터 2018년 최근 10년간 국내에서 발행된 학회지에서 모래놀이치료 관련 연구 205편을 분석 하고자 한다. 10 년간 발행된 모래놀이치료 관련 연구의 흐름을 파악하여 지금까지 모래놀 이치료 연구가 진행된 것과 앞으로의 발전 방향을 파악하여 모래놀이치료의 학문적 발전의 방향성을 제시하고자 한다.

\section{2. 연구문제}

1) 모래놀이치료 연구 논문의 기본사항(연도별 게제논문, 학술지 등급별) 연구동향은 어떠 한가?

2) 모래놀이치료 연구 논문의 연구주제별 연구동향은 어떠한가?

3) 모래놀이치료 연구 논문의 연구대상별 연구동향은 어떠한가?

4) 모래놀이치료 연구 논문의 연구방법별 연구동향은 어떠한가?

5) 모래놀이치료 연구 논문의 치료개입과 회기별 연구동향은 어떠한가?

\section{ㅍ. 연구방법}

\section{1. 분석대상}

본 연구에서는 한국의 모래놀이치료 연구동향을 살펴보기 위하여 한국교육학술정보원 (KERIS)과 연구정보서비스 사이트(RISS, http://www.riss4u.net)에서 주제어 '모래놀이치료'로 한 국에서 출판된 학회지 논문을 검색하여 자료를 수집하였다. 그중 발행연도가 2009년부터 2018년까지인 국내 논문 총 205편의 논문을 분석대상으로 하였다.

\section{2. 분석 기준}

모래놀이치료 연구동향 분석을 위해 수집된 자료들의 출판연도, 출판 학회지, 출판 학회 지의 등급이 포함된 기본사항과 연구주제, 연구대상의 연령과 특성, 연구방법, 모래놀이치 
Journal of Symbols \& Sandplay Therapy, Vol.11 No.1.

료 관련 개입방법과 회기로 나누어 구성하였다.

\section{1) 모래놀이치료 연구의 기본사항}

본 연구에서 기본사항으로 정한 것은 모래놀이치료 연구가 출판된 연도와 출판 학회지, 출판 학회지의 등급이다. 2009년부터 2018년까지 총 10년간의 모래놀이치료 관련 출판 분 포를 확인하고 출판된 학회지와 학회지의 등급 기준에 따라 자료를 분류하였는데, 학회지 의 등급 기준은 2018년으로 하였다.

\section{2) 모래놀이치료 연구주제}

본 연구의 연구주제 동향을 알아보기 위하여 Bulboltz와 Williams(1999), 기정희 외 (2011), 김예주 • 이윤주(2012)의 분석틀을 참고하여 모래놀이치료 연구에 맞게 수정 - 보완하여 사용 하였다. 하위항목은 총 10 개로 자아성장, 심리정서, 스트레스, 의사소통 및 대인관계, 부적 응 행동, 부모 관련, 치료자 관련, 진단 장애 관련, 기타(상징연구), 혼합이다. 구체적 내용은 표 1 과 같다.

\section{표 1. 연구주제 분류}

\begin{tabular}{ll}
\hline \multicolumn{1}{c}{ 연구주제 } & 내용 \\
\hline (1) 자아성장 & 자아발달 및 강화, 여성성 및 남성성 발달, 자아존중감, 개성화 과정 등 \\
\hline (2) 심리정서 & 불안, 우울, 공격성, 내재화 및 외현화 등 \\
\hline (3) 스트레스 & 외상 후 스트레스, 복합외상, 양육스트레스 등 \\
\hline (4) 의사소통 및 대인관계 & 사회성, 의사소통 방식과 유형, 이성관계, 또래관계 등 \\
\hline (5) 부적응 행동 & 학교 부적응, 사회 부적응 등 \\
\hline (6) 부모 관련 & 분리, 애착, 결손가정, 부모-자녀 관계 등 \\
\hline (7) 치료자 관련 & 소진, 치료사 경험 등 \\
\hline (8) 진단 장애 관련 & 신체적 - 정신적 장애 진단 \\
\hline (9) 기타 & (1) (8)에 속하지 않는 연구주제 및 상징연구 \\
\hline (10) 혼합 & (1) (9) 중 2개 이상 포함된 연구주제 \\
\hline
\end{tabular}

\section{3) 모래놀이치료 연구의 연구대상}

연구대상 유형은 Buboltz(1999), 이숙영과 김성희(2003), 정진호(2012)의 분석틀을 본 연구에 맞게 수정·보완하여 사용하여 유아, 아동, 청소년, 성인, 노인 그리고 혼합으로 나누었다. 그 구체적 기준은 다음 표 2와 같다. 
표 2. 연구대상 분류

\begin{tabular}{cl}
\hline 연구대상 & 기준 \\
\hline (1) 유아 & 만 5세 미만의 어린이집, 유치원에 다니는 학령 전 유아 \\
\hline (2) 아동 & 만 6세 이상 만 12 세 미만의 초등학교에 다니는 아동 \\
\hline (3) 청소년 & 만 13 세 이상 만 18 세 미만의 중·고등학교에 다니는 청소년 \\
\hline (4) 성인 & 만 18 세 이상의 성인 \\
\hline (5) 노인 & 만 65세 이상의 노인 \\
\hline (6) 혼합 & (1) (5) 중 2 개 이상의 연구대상이 포함된 것 \\
\hline
\end{tabular}

또한, 연구대상의 특징에 따라 일반 개인, 가족 관련, 치료자, 외국인, 특정직업, 의학적 진단, 혼합의 총 7 가지 하위항목으로 분류하였다. 분류기준에 대한 구체적 내용은 다음과 같다.

표 3. 연구대상의 특징 분류

\begin{tabular}{ll}
\hline 연구대상 & \multicolumn{1}{c}{ 기준 } \\
\hline (1) 일반 개인 & 심리적 어려움이 있거나 (2) (6)에 속하지 않는 연구대상 \\
\hline (2) 가족 관련 & 부모, 조부모 등이 연구대상인 경우 \\
\hline (3) 치료자 & 치료자가 연구대상인 경우 \\
\hline (4) 외국인 & 외국인이 연구대상인 경우 \\
\hline (5) 특정직업 관련 & 치료자를 제외한 특정 직업군이 연구대상인 경우 \\
\hline (6) 의학적 진단 & 신체적 · 정서적 장애 진단을 받은 연구대상 \\
\hline (7) 혼합 & (1) (6) 중 2개 이상의 연구대상이 포함된 것
\end{tabular}

\section{4) 모래놀이치료 연구방법}

연구방법 분류는 강유리·이여랑(2011)이 사용한 분류 방법을 수정 - 보완하여 사용하였 다. 이는 양적연구, 질적연구, 혼합연구, 상징연구, 기타로 총 5가지의 하위항목이 있다. 양 적연구는 통계적인 방법을 사용한 연구로 실험연구, 비교연구, 상관관계 연구 를 의미한다. 질적연구는 양적연구로는 알 수 없는 현상학적, 해석학적 탐구와 사례연구, 문헌연구 등이 포함된다(황혜정, 2019). 혼합연구는 양적연구와 질적연구 두 가지 방법을 함께 사용한 방법 이다. 상징연구는 상징에 대한 보편적 의미와 모래놀이치료에서 나타난 상징적 표현 등을 분석하는 연구이다. 
Journal of Symbols \& Sandplay Therapy, Vol.11 No.1.

5) 모래놀이치료 관련 특성에 따른 연구

모래놀이치료가 어떤 방식으로 개입되었는지 몇 회기가 진행되었는지에 따라 분류하였 다. 개입방법은 개별, 집단, 혼합의 3 가지 하위항목으로 구분하였다. 개별은 1 대 1 치료를 진 행한 경우, 집단은 1 명의 치료사와 2 명 이상의 연구대상이 참여한 경우, 혼합은 한 연구 안 에 두 가지 방법이 모두 사용된 경우를 의미한다.

\section{3. 자료처리}

연구문제에 대한 연구결과를 도출하기 위해 양적자료를 통계 프로그램 SPSS 23.0 통계 프 로그램을 활용하여 분석하였다. 분석방법으로는 기술통계와 빈도분석을 이용하여 모래놀이 치료 연구의 기본사항과 연구주제, 연구대상의 연령과 특성, 연구방법, 모래놀이치료 관련 개입방법 및 회기에 따른 빈도와 백분율을 구하였다.

\section{III. 연구결과}

1. 모래놀이치료 연구의 기본사항 동향

\section{1) 연도별 게재논문 분포}

국내 학술지에 모래놀이치료 연구는 2009년부터 2018년까지 총 205편의 논문이 게재되었 다. 발표된 논문을 연도별로 살펴보면 표 4와 같다. 2009년부터 2011년까지 증가하는 추세

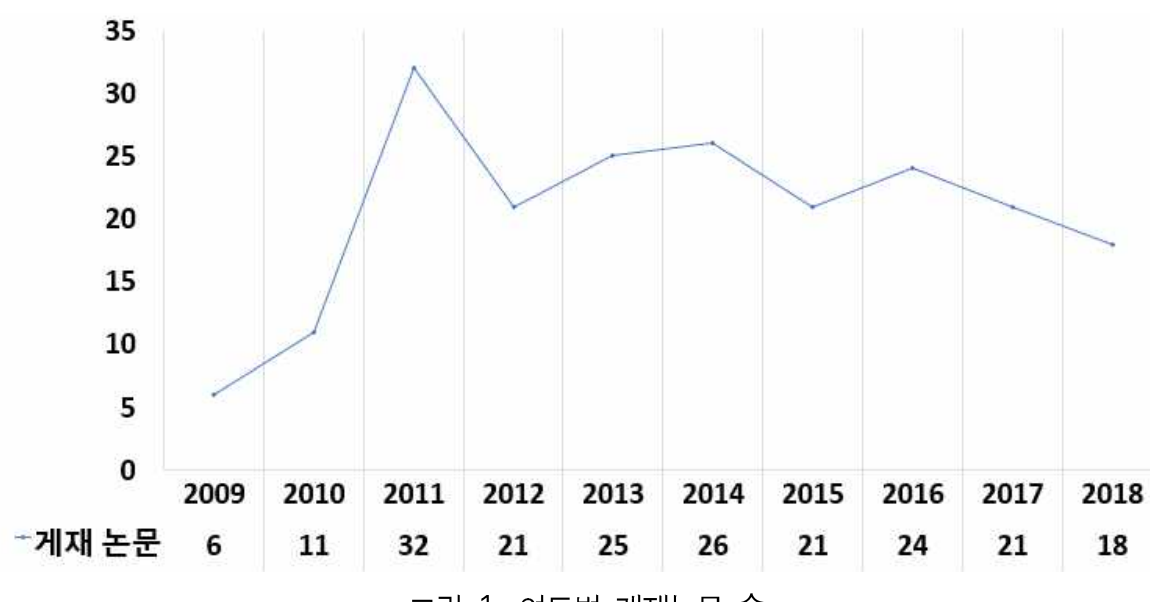

그림 1. 연도별 게재논문 수 
였으나, 2011년 가장 많은 논문 32편(15.61\%)이 게재된 이후 2012년부터 2018년까지는 24편 이 발표된 2016년을 제외하고 논문게재 수가 다소 감소하였다.

표 4. 연도별 게재논문 분포

\begin{tabular}{ccc}
\hline 구분 & 논문 수(n) & 백분율(\%) \\
\hline 2009 & 6 & 2.93 \\
2010 & 11 & 5.37 \\
2011 & 32 & 15.61 \\
2012 & 21 & 10.24 \\
2013 & 25 & 12.20 \\
2014 & 26 & 12.68 \\
2015 & 21 & 10.24 \\
2016 & 24 & 11.71 \\
2017 & 21 & 10.24 \\
2018 & 18 & 8.78 \\
총합 & 205 & 100 \\
\hline
\end{tabular}

\section{2) 학술지 등급별 분포}

국내 학술지 등급별 동향은 표 5에서 제시하였다. 한국학술지인용색인(KCI; KOREA CITATION INDEX) 2019년 기준으로 등재 학술지에 14편, 등재후보 학술지에 3편, 미등재지 에 14 편이 게재되었다. 등재 학술지인 <상징과 모래놀이치료>에 74 편(35.92\%)으로 가장 많 은 논문이 게재되었으며, 그 다음으로는 미등재지에 속한 <모래놀이치료연구>에 52편 (25.37\%), 등재 학술지인 <놀이치료연구>에 9편(4.37\%), 등재후보 학술지인 <한국놀이치료 학회>와 <한국아동심리치료학회>에 각각 8편씩(3.88\%), <아동복지연구>에 7편(3.40\%)이 게재되었다.

표 5. 국내 학술지 등급별 분포

\begin{tabular}{cccc}
\hline 구분 & 학회지명 & 논문 수(n) & 백분율(\%) \\
\hline & Family and Environment Research & 6 & 2.93 \\
등재 학술지 & Korean Journal of Child Studies & 3 & 1.46 \\
& 가족과 가족치료 & 1 & 0.49 \\
& 놀이치료연구 & 9 & 4.39 \\
\hline
\end{tabular}


Journal of Symbols \& Sandplay Therapy, Vol.11 No.1.

표 5. 국내 학술지 등급별 분포

(계속)

\begin{tabular}{|c|c|c|c|}
\hline 구분 & 학회지명 & 논문 수(n) & 백분율(\%) \\
\hline \multirow{10}{*}{ 등재 학술지 } & 목회와 상담 & 1 & 0.49 \\
\hline & 상징과 모래놀이치료 & 74 & 36.10 \\
\hline & 아동학회지 & 5 & 2.43 \\
\hline & 열린부모교육연구 & 1 & 0.49 \\
\hline & 유아교육학논집 & 1 & 0.49 \\
\hline & 재활심리연구 & 2 & 0.98 \\
\hline & 청소년학연구 & 1 & 0.49 \\
\hline & 한국가정관리학회지 & 4 & 1.95 \\
\hline & 한국기독교상담학회지 & 2 & 0.98 \\
\hline & 한국콘텐츠학회논문지 & 2 & 0.98 \\
\hline \multirow{3}{*}{ 등재후보 학술지 } & 아동복지연구 & 7 & 3.41 \\
\hline & 한국놀이치료학회지 & 8 & 3.89 \\
\hline & 한국아동심리치료학회지 & 8 & 3.89 \\
\hline \multirow{14}{*}{ 미등재지 } & Natural Science & 1 & 0.49 \\
\hline & 모래놀이치료연구 & 52 & 25.36 \\
\hline & 발달지원연구 & 1 & 0.49 \\
\hline & 사회과학논총 & 1 & 0.49 \\
\hline & 상담과지도 & 1 & 0.49 \\
\hline & 생애학회지 & 1 & 0.49 \\
\hline & 아동가족치료연구 & 6 & 2.92 \\
\hline & 에니어그램연구 & 1 & 0.49 \\
\hline & 연세상담코칭연구 & 1 & 0.49 \\
\hline & 중독과 복지 & 1 & 0.49 \\
\hline & 지성과 창조 & 1 & 0.49 \\
\hline & 통합치료연구 & 1 & 0.49 \\
\hline & 한국부모놀이치료학회지 & 1 & 0.49 \\
\hline & 한영연구논문 & 1 & 0.49 \\
\hline \multicolumn{2}{|c|}{ 총합 } & 205 & 100 \\
\hline
\end{tabular}




\section{2. 모래놀이치료 연구주제 동향}

국내 논문의 연구주제를 살펴보면, 기타(상징연구)주제가 66편(32.20\%)으로 가장 많았으며, 치료자 관련 주제가 2 편 $(0.98 \%)$ 으로 가장 낮았다. 이외 혼합 주제가 43편(20.98\%), 자아성장 주제는 21편(10.24\%), 심리정서 주제가 16편(7.80\%), 스트레스 주제가 15편(7.32\%), 부적응 행 동과 부모 관련 주제가 각각 13 편(6.34\%), 의사소통 및 대인관계 주제가 10 편(4.88\%) 순으로 나타났다.

표 6. 연구주제 동향

\begin{tabular}{ccc}
\hline 구분 & 논문 수(n) & 백분율(\%) \\
\hline 자아성장 & 21 & 10.24 \\
심리정서 & 16 & 7.80 \\
스트레스 & 15 & 7.32 \\
의사소통 및 대인관계 & 10 & 4.88 \\
부적응 행동 & 13 & 6.34 \\
부모 관련 & 13 & 6.34 \\
치료자 관련 & 2 & 0.98 \\
진단 장애 관련 & 6 & 2.93 \\
기타(상징연구) & 66 & 32.20 \\
혼합 & 43 & 20.98 \\
총합 & 205 & 100 \\
\hline
\end{tabular}

\section{3. 모래놀이치료 연구의 연구대상 동향}

\section{1) 연구대상의 연령별 분포}

연구대상이 없는 상징 및 이미지, 주제, 문헌연구, 연령이 미기재된 연구 등이 49편으로, 이를 제외한 나머지 총 156 편의 자료를 분석한 결과는 표 7 과 같다. 먼저, 연구대상의 연령 별 분포의 결과를 살펴보면, 아동을 대상으로 한 논문이 74 편(47.44\%)으로 가장 많았고, 그 다음은 성인을 대상으로 한 연구로 46편(29.49\%)이었으며, 청소년 대상이 23편(14.74\%), 다 양한 연령대로 된 혼합 대상은 7편(4.49\%)이었다. 노인을 대상으로 한 연구는 없는 것으로 나타났다. 
Journal of Symbols \& Sandplay Therapy, Vol.11 No.1.

표 7. 연구대상의 연령별 분포

\begin{tabular}{ccc}
\hline 구분 & 논문 수(n) & 백분율(\%) \\
\hline 유아 & 6 & 3.85 \\
아동 & 74 & 47.44 \\
청소년 & 23 & 14.74 \\
성인 & 46 & 29.49 \\
노인 & 0 & 0 \\
혼합 & 7 & 4.49 \\
총합 & 156 & 100 \\
\hline
\end{tabular}

\section{2) 연구대상의 특성별 분포}

국내 모래놀이치료의 연구대상의 특성을 살펴본 결과, 연구대상이 없는 상징 및 이미지, 주제, 문헌연구, 특성이 미기재된 연구가 총 51 편이었고, 이를 제외한 나머지 총 154 편의 자료를 처리한 결과는 표 8과 같다. 연구대상의 특징 중 일반 개인이 96편(62.34\%)으로 가 장 많았으며, 가족 관련(부부, 부모-자녀, 형제, 한부모 가정 등)은 27 편(17.53\%), 외국인 관 련(이주민, 유학생, 난민 등)은 16 편(10.39\%), 의학적 진단 관련(심리·정서적, 신체적 등)은 12 편(7.79\%), 치료자 관련(수련생, 치료자-내담자 등)은 2 편(1.30\%), 혼합 1 편( $0.65 \%)$, 특정직 업 관련은 0 편 순으로 나타났다.

표 8. 연구대상의 특성별 분포

\begin{tabular}{ccc}
\hline 구분 & 논문 수(n) & 백분율(\%) \\
\hline 일반 개인 & 96 & 62.34 \\
가족 관련 & 27 & 17.53 \\
치료자 & 2 & 1.30 \\
외국인 & 16 & 10.39 \\
특정직업 관련 & 0 & 0 \\
의학적 진단 관련 & 12 & 7.79 \\
혼합 & 1 & 0.65 \\
총합 & 156 & 100 \\
\hline
\end{tabular}




\section{4. 모래놀이치료 연구방법 동향}

연구방법 동향을 살펴보면, 질적연구가 89편(43.41\%)으로 가장 많은 부분을 차지하였으며, 상징연구 46편(22.44\%), 양적연구 41편(20.00\%), 혼합연구 21 편(10.24\%), 기타 8편(3.90\%)의 순으로 나타났다.

표 9. 연구방법 동향

\begin{tabular}{ccc}
\hline 구분 & 논문 수(n) & 백분율(\%) \\
\hline 양적연구 & 41 & 20.00 \\
질적연구 & 89 & 43.41 \\
혼합연구 & 21 & 10.24 \\
상징연구 & 46 & 22.44 \\
기타 & 8 & 3.90 \\
총합 & 205 & 100 \\
\hline
\end{tabular}

\section{5. 모래놀이치료 관련 특성에 따른 연구 동향}

\section{1) 모래놀이치료 개입별 분포}

국내 모래놀이치료에서 개입을 다루지 않은 논문 55편을 제외한 150 편을 자료 처리한 결 과는 표 10 과 같다. 모래놀이치료 개입을 개별, 집단, 혼합(개별과 집단 병행)으로 나누어 살펴본 결과 대부분 개별개입으로 총 논문 수는 125 편(83.33\%)이었다. 집단으로 개입한 경 우는 21 편(14.00\%), 개별과 집단을 혼용하여 개입한 경우는 4 편(2.67\%)으로 나타났다.

표 10. 모래놀이치료 개입별 분포

\begin{tabular}{ccc}
\hline 치료개입 & 논문 수(n) & 백분율(\%) \\
\hline 개별 & 125 & 83.33 \\
\hline 집단 & 21 & 14.00 \\
\hline 혼합 & 4 & 2.67 \\
\hline 총합 & 150 & 100 \\
\hline
\end{tabular}


Journal of Symbols \& Sandplay Therapy, Vol.11 No.1.

\section{2) 모래놀이치료 회기별 분포}

국내 모래놀이치료에서 개입이 없거나 치료 회기를 미기재한 연구 58편을 제외한 총 147 편을 자료 처리하였다. 치료 회기별 연구동향 결과는 표 11 과 같다. 먼저, 치료회기는 21 회 기 이상이 60편(40.82\%)으로 가장 많았으며, 그다음은 11-15회기가 33편(2.45\%), 6-10회기는 28편(19.05\%), $16-20$ 회기는 12 편(8.16\%), 5 회기 이하인 경우 8 편(5.44\%), 기타 6편(4.08\%)의 순 으로 나타났다.

표 11. 모래놀이치료 회기별 분포

\begin{tabular}{ccc}
\hline 치료 회기 & 논문 수 $(\mathrm{n})$ & 백분율(\%) \\
\hline 5 회기 이하 & 8 & 5.44 \\
$6 \sim 10$ 회기 & 28 & 19.05 \\
$11 \sim 15$ 회기 & 33 & 22.45 \\
$16 \sim 20$ 회기 & 12 & 8.16 \\
21 회기 이상 & 60 & 40.82 \\
기타 & 6 & 4.08 \\
총합 & 147 & 100 \\
\hline
\end{tabular}

\section{IV. 결론 및 제언}

본 연구는 모래놀이치료 연구에 대한 연구동향을 조사하여 현재 모래놀이치료의 위치를 파악함과 동시에 모래놀이치료의 학문적 발전을 위해 향후 연구의 방향을 제시하고자 하였 다. 이를 위하여 2009년부터 2018년까지 출판된 국내 학술지 논문 205편을 기초자료로 수 집하였으며, 수집된 자료를 출판연도와 등재지 및 미등재지, 연구주제, 연구대상의 연령과 특징, 연구방법, 모래놀이치료 관련 특성(개입, 회기)을 조사하고 비교·분석하였다. 위에서 기술한 연구 동향과 수집된 자료를 토대로 한 연구결과의 함의와 향후 연구의 방향을 위한 제언은 다음과 같다.

첫째, 2010년 강유리와 이예랑의 국내 모래놀이치료 연구 동향의 결과에서 모래놀이치료 출판된 논문의 학술지가 총 36 편이 게재된 이후 10 년간 출판된 논문은 총 205 편으로 등재 학술지에 게재된 논문은 112 편, 등재후보 학술지에는 23 편, 미등재지에 70 편이 게재되었다. 모래놀이치료라는 한정된 주제를 가지고 205편의 논문이 국내에서 출판되었다는 점은 높이 평가할 만한 일이 아닐 수 없으며, 한국임상모래놀이치료학회의 <상징과 모래놀이치료>가 
등재 학술지로 선정되면서 보다 체계적이고 활발한 연구 활동이 이루어졌다는 것을 볼 수 있다.

둘째, 연구주제로는 기타(상징연구)가 가장 많았고, 자아성장과 심리정서, 스트레스, 부적 응 행동, 부모 관련 등의 다양한 주제가 그다음을 이었다. 모래놀이치료가 분석심리학에 기 반한 학문이므로 상징에 관한 연구는 지속되어야 하고 상징에 관한 연구가 깊어지고 다양 해질수록 모래놀이치료의 깊이가 깊어지며 발전하리라 생각된다. 아쉬운 점은, 모래놀이치 료는 치료자가 중요한 치료 도구인데 치료자에 대한 연구가 현저하게 부족한 실정으로 향 후 모래놀이치료자와 관련된 연구가 수행되어야 할 것으로 보인다.

셋째, 연구대상별 동향에서 연구대상의 연령별 분포를 살펴본 결과, 아동 관련 연구가 74 편으로 압도적으로 많았으며, 성인과 청소년 대상의 연구가 그다음으로 활발하였다. 노인을 대상으로 하는 연구가 없었다는 점이 특이한 사항으로 앞으로 노인에 관한 연구가 더 많아 져야 할 것으로 생각된다. 인간의 수명은 날로 길어지고 죽을 때까지 인간의 존엄성을 유 지하기 위해 노인 복지에 관한 관심과 투자가 증가하고 있는 지금의 현상은 바람직하며 모 래놀이치료 또한 노인을 대상으로 더 활발한 연구가 수행되기를 기대한다. 또한, 연구대상 의 특징 중 일반 개인이 절반 이상으로 다수 연구에서 다루진 반면, 특정 직업군을 연구대 상으로 한 연구는 전혀 이루어지지 않았다. 향후 보다 다양한 직업군을 대상으로 폭넓은 모래놀이치료 연구가 이루어져야 할 것이다.

넷째, 연구방법으로는 질적연구가 89편으로 가장 많았고, 상징연구가 46편, 양적연구가 41 편이 게재되었다. 모래놀이치료 연구가 연구참여자의 경험과 이해를 추구하는 방향으로 서술되며 연구자도 중요한 연구도구로서 적극적인 역할을 하는 질적연구(조흥식 외, 2005) 가 많이 이루어짐을 알 수 있었다. 이와 더불어 모래놀이치료가 가져오는 치료 효과를 일 반화시키기 위해서는 양적연구도 활발히 진행되어야 할 것으로 보인다.

다섯째, 치료개입별 연구동향에서는 개별치료가 125 편으로 가장 많았고, 21 회기 이상 진 행된 치료가 진행된 경우가 60 편으로 전체의 $40 \%$ 를 차지하였다. 향후 연구에서는 모래놀 이치료가 시간이 지난 후에 어떠한 결과를 낳았는지에 대한 종단 연구를 수행할 필요가 있다.

마지막으로, 본 연구는 자료수집을 위해 국내교육학술정보원(KERIS)와 연구정보서비스 사 이트를 이용하여 이미 전문 학술지에 발표되었지만, 이 사이트로 찾을 수 없었던 자료들에 대해서는 분석할 수가 없었던 한계가 있었다.

모래놀이치료 연구는 지난 2009년부터 2011년 연구의 10년 보다 최근 10년간 2배 이상 많은 논문이 발표되었다. 하지만 당시에도 제시되었던 연구대상의 다양성은 최근 연구동향 에서도 더 발전되어야 할 부분으로 제시되었다. 모래놀이치료의 연구가 단순히 양적 발전 이 아닌 질적인 발전을 이루기 위해서 보다 더 심층적이면서도 넓은 분야에서의 연구가 진 
Journal of Symbols \& Sandplay Therapy, Vol.11 No.1.

행되어야 할 것이다.

\section{참고문헌}

강유리, 이여랑 (2010). 국내 모래놀이치료 연구동향: 모래놀이치료 관련논문을 중심으로 (1994 2009). 아동가족치료연구, 8, 79-96.

강인애, 장미경, 김진경, 김민경 (2011). 모래놀이치료가 아동상담기관 내원아동 부모의 우울

감과 우울뇌파수치에 미치는 효과. 아동복지연구, 9(3), 39-60.

고은경, 정계숙 (2010). 관계적 외상을 극복하는 연행의 상징 : 가정폭력을 경험한 7세 남아

의 모래놀이치료 사례. 모래놀이치료연구, 6(2), 1-24.

고은경, 정계숙 (2011). 아동의 모래놀이치료에서 물(水)을 통한 연행의 상징 분석. 兒童學會

誌, 32(3), 185-202.

고은경, 정계숙 (2011). 이주 다문화 가정의 여아가 형상화한 이야기의 공간적 상징: 고래-요

나 콤플렉스 유형의 민담 분석을 토대로. 모래놀이치료연구, 7(3), 1-29.

고은경 (2012). 방임된 10세 여아의 생일축하파티 음식의 상징적 의미. 모래놀이치료연구,

8(2), 1-19.

고은경, 정계숙, 류수민 (2013). 모래놀이치료에서 나타난 자아강화 과정의 상징적 의미: 애

착 관련 문제행동을 보이는 아동 중기 남아를 중심으로. 생애학회지, 3(2), 21-38.

곽수경, 서미아 (2018). 지역아동센터 아동의 우울, 공격성 및 자아발달 단계에 대한 내담자

중심 모래놀이치료의 효과. 상징과 모래놀이치료, 9(2), 1-22.

곽현정 (2014). 부와의 사별로 인한 PTSD의 중년 여성의 사례. 모래놀이치료연구, 10(1),

109-152.

곽현정 (2014). 한국 샤머니즘에 나타난 마을 당산나무의 위치와 모래상자의 공간에 대한

비교. 모래놀이치료연구, 10(2), 33-47.

곽현정 (2017). 학교모래놀이 집단상담이 아동의 정서, 행동에 미치는 임상효과. 한국콘텐츠

학회논문지, 18(12), 54-61.

구세경 (2018). 모래놀이 상담사의 교육분석 경험에 대한 질적 연구. 아동가족치료연구, 16 , $1-24$.

구세경, 한유진 (2018). 인격의 일부로 그림자를 통합해가는 아동 모의 모래놀이 사례연구.

놀이치료연구, 22(3), 87-104.

권미라 (2015). 재생의 의미로서의 해골의 변환적 상징성. 상징과 모래놀이치료, 6(1), 1-20.

권미라 (2017). A 10-Year-Old Girl's Overcoming the Negative Mother Complex and Its 
Relationship to Ego Development. 상징과 모래놀이치료, 8(1), 1-32.

권미선 (2010). 모와 애착이 결핍된 아동의 모래놀이치료에서 보이는 공통된 의미 고찰과

자아존중감 및 상호작용 변화에 관하여. 통합치료연구, 2(2), 49-71.

기윤영, 한유진 (2014). 의사소통 중심의 모래놀이치료 프로그램이 모-자간의 의사소통과 상

호작용 및 아동의 자기효능감과 모의 양육효능감에 미치는 효과. 한국아동심리치료학회

지, 9(3), 19-46.

기정희, 이숙미, 김춘경, 정종진, 최웅용. (2011). 한국 미술치료의 연구동향: 한국미술치료학

회지 게재논문 (1994 2010)을 중심으로. 미술치료연구, 18, 463-483.

김경남 (2011). 감정조절의 어려움을 지닌 9세 소년의 모래놀이치료 사례. 상징과 모래놀이치

료, 2(1), 29-53.

김경남 (2012). 우물. 상징과 모래놀이치료, 3(2), 55-72.

김경남 (2017). 개성화 과정에서 경험한 대극 통합의 상징: 어머니. 상징과 모래놀이치료, 8(2),

$41-56$.

김경은 (2017). 자아 강화를 하는 여아의 모래놀이치료 사례연구. 모래놀이치료연구, 13(2),

$1-29$.

김경희 (2013). 모래상자에 나타나는 영웅신화론 주제 분석. 모래놀이치료연구, 9(1), 41-65.

김광웅 (2011). 심리치료에서 상징물 사용의 임상적 가치. 상징과 모래놀이치료, 2(1), 1-14.

김금란, 한유진 (2012). 구조화된 집단모래놀이치료 프로그램이 아동의 자기지각 및 자아탄

력성에 미치는 효과. 한국아동심리치료학회지, 7(1), 27-48.

김도연 (2011). 애착 문제로 내원한 아동의 모래놀이치료 사례연구. 놀이치료연구, 15(2),

57-74.

김도희 (2010). 저소득층 방임 아동의 모래놀이치료 질적 연구. 한국놀이치료학회지, 13(3),

23-38.

김민경 (2015). 모래놀이치료에서의 ‘두꺼비'상징에 대한 고찰. 모래놀이치료연구, 11(2), 6-25.

김민경, 이미숙, 장미경, 김진경 (2011). 가정폭력 피해여성의 분노와 뇌기능 지수의 변화에

대한 모래놀이치료효과. 아동복지연구, 9(3), 1-18.

김사라 (2012). 연금술과 '털북숭이 공주' 관점에서 본 가정폭력 피해여성 사례의 모래놀이

치료. 모래놀이치료연구, 8(1), 21-41.

김선숙, 김기현 (2016). 정서불안 아동과 주의력 결핍 아동의 모래놀이치료 과정에서 표현된

상처와 치유 주제에 대한 분석. Family and Environment Research, 54(6), 631-642.

김선숙 (2018). 내담아동집단과 일반아동집단의 성별에 따른 모래 놀이치료 상징물 사용 경

향 비교 분석. 모래상자치료연구, 8(1), 60-81.

김선영, 장미경 (2012). 모래놀이치료가 상담기관에 내원한 아동부모의 스트레스 및 스트레 
Journal of Symbols \& Sandplay Therapy, Vol.11 No.1.

스 관련 뇌파수치에 미치는 효과. 상징과 모래놀이치료, 3(2), 25-36.

김선영, 김장회 (2013). 적대적 반항장애 아동의 장기 모래놀이치료 단일사례연구. 재활심리 연구, 20(3), 427-462.

김선영, 김장회 (2013). 적대적 반항장애 아동의 장기 모래놀이치료 단일사례연구. 재활심리 연구, 20(3), 427-462.

김소온 (2014). 모래놀이치료가 청소년 자녀 어머니의 자아분화, 우울 및 모-자녀 관계 증진

에 미치는 효과. 상징과 모래놀이치료, 5(1), 1-12.

김수연 (2016). 모래놀이치료를 병행한 원가족작업 사례연구. 가족과 가족치료, 24(1), 73-99.

김신옥 (2010). 엄마의 자살을 목격한 10 세 여아의 모래놀이치료를 통한 애도. 모래놀이치료

연구, 6(2), 25-65.

김선옥, 이의철 (2011). 모래놀이가 아동의 자아존중감과 사회성에 미치는 효과성 연구. 모래

놀이치료연구, 7(4), 57-79.

김신화, 심희옥 (2018). 사회성과 정서에 어려움이 있는 초등학생 남아의 모래놀이치료사례

연구. Family and Environment Research, 56(6), 589-601.

김영미, 장미경, 김민경, 김진경 (2012). 자녀가 상담을 받고 있는 부모의 양육스트레스와 타

액 코티졸에 미치는 모래놀이치료 효과. 兒童學會誌, 33(3), 83-97.

김유선 (2018). 중국 조선족 부모 별거 아동과 부모 동거 아동의 모래놀이치료 이야기 표현

과 상징성 표현 비교. 상징과 모래놀이치료, 9(1), 1-15.

김정국 (2013). 꿈에 나타난 백호의 상징에 대한 소고. 모래놀이치료연구, 9(2), 31-49.

김진안 (2015). 모래놀이치료를 활용한 학교상담이 청소년의 정서 - 행동문제에 미치는 효과.

모래놀이치료연구, 11(2), 28-51.

김태영 (2010). 모래놀이치료가 ADHD 성인의 우울 및 불안에 미치는 효과. 상징과 모래놀이

치료, 1(1), 15-40.

김태균 (2010). BUTTERFLY: SYMBOL OF INDIVIDUATION. 상징과 모래놀이치료, 1(1), 1-13.

김혜림, 김유진 (2015). 집단모래놀이치료가 스마트폰중독 청소년의 또래애착과 충동성 및

사회적 불안에 미치는 효과. 상징과 모래놀이치료, 6(2), 1-12

김혜선 (2018). 곰의 상징적 의미. 모래놀이치료연구, 14(1), 1-15.

김혜영 (2016). 네팔 지진 피해 아동의 모래놀이치료 상징 및 주제연구. 아동복지연구, 14(1), $39-56$.

김혜자 (2011). 유아기 모성성의 상실로 학교부적응을 보이는 중학교 남학생. 모래놀이치료연

구, 7(2), 29-57.

김혜자 (2017). 원(圓)의 상징. 모래놀이치료연구, 13(1), 1-20.

김활란 (2015). 개성화의길을가는중년여성의모래놀이치료사례연구 - 만다라모형의변환을중심 
으로 -. 모래놀이치료연구, 11(2), 54-84.

나경희, 장미경 (2017). 모래놀이치료가 알코올중독자 자녀의 내면화된 수치심과 자기표현에

미치는 효과. 상징과 모래놀이치료, 8(1), 33-48.

노명자 (2018). 대인관계가 어려운 중년 여성의 남성성 의식화 과정에 대한 사례연구. 모래

놀이치료연구, 14(1), 1-34.

류희정 (2012). 인어공주: 의식화로 가기 위한 여성성. 상징과 모래놀이치료, 3(2), 73-89.

맹주영, 장미경 (2014). 모래놀이치료가 시각장애 대학생의 불안과 자아존중감 및 사회성에

미치는 효과. 상징과 모래놀이치료, 5(1), 27-44.

문수영 (2016). 복합 외상 후 스트레스 문제를 가진 20대 여성의 모래놀이치료 사례연구. 모

래놀이치료연구, 1967(2), 1-38.

박부진 (2014). 한국의 전통신앙과 의례에서 본 나무의 상징적 의미. 모래놀이치료연구, 10(1),

79-94.

박상민, 김동일 (2011). 잃어버린 여성성을 회복하고 진정한 여성으로 거듭난 중년여성의 모

래놀이치료 사례연구. 한국아동심리치료학회지, 6(2), 1893-1914.

박선영 (2016). 모래놀이치료에서의 '다리' 상징에 대한 고찰, 모래놀이치료연구, 1967(2),

$1-15$.

박선영 (2017). 모래놀이치료를 통해 청소년기 통과의례를 한 남자 중학생의 사례. 모래놀이

치료연구, 13(1), 1-25.

박슬기, 김효원, 박부진 (2013). 집단모래놀이치료가 학교폭력 피해 청소년의 자기표현과 학

교적응에 미치는 효과. 청소년학연구, 20(8), 175-202.

박애규 (2015). 고양이: 여성성의 상징. 상징과 모래놀이치료, 6(1), 37-53.

박애규 (2016). 근친 성학대 외상을 가진 남자청소년의 모래놀이치료 사례연구. 상징과 모래

놀이치료, 7(2), 1-28.

박정옥 (2014). 쥐의 상징에 대한 연구. 모래놀이치료연구, 10(2), 49-68.

박정희 (2012). 미국에 이민간 한 중년 여성의 개성화 과정. 모래놀이치료연구, 8(1), 43-71.

박종미 (2018). 모래놀이치료에 나타난 경주 지진 피해지역 유아의 지진 이미지 연구, 상징

과 모래놀이치료 9(2), 31-45.

박지영, 박부진 (2011). 집단모래놀이치료가 아동의 사회불안에 미치는 효과. 모래놀이치료연

구, 7(4). 1-22.

박지영, 박부진 (2012). 자아강도가 약한 아동의 집단모래놀이치료 사례연구. 아동가족치료연

구, $10,35-52$.

박행자, 한유진 (2011). 분석심리학적 관점에서 본 물의 상징에 대한 연구. 모래놀이치료,

$7(2), 59-72$. 
Journal of Symbols \& Sandplay Therapy, Vol.11 No.1.

박혜영 (2015). 불안정 애착 유형 아동에 대한 모래놀이치료 효과 연구. 연세상담코칭연구, 3, 87-110.

반정환, 박창우 (2017). 모래놀이에서 동굴상징. 한국놀이치료학회지(놀이치료연구), 20(3), $235-251$.

반평자, 우주영 (2013). 모래놀이치료를 통한 가정해체위기 아동의 비행과 공격행동 변화 및 내용주제 분석. 재활심리연구, 20(1), 65-100.

부정민 (2013). 가정폭력을 목격한 여아의 모래놀이치료 사례연구. 아동복지연구, 11(3), $115-152$.

부정민 (2013). 선택적 함구증을 보인 6세 소녀의 모래놀이치료사례. 아동복지연구, 11(2), $1-40$.

부정민 (2014). 제주의 문(門) “정낭”의 상징적 의미에 관한 연구- 모래놀이치료를 중심으로-.

상징과 모래놀이치료, 5(2), 11-34.

부정민 (2014). 선택증 함묵아에 대한 모래놀이치료 사례 연구: 시간의 흐름과 함께 계속되

는 삶의 이야기. 상징과 모래놀이치료, 5(1), 45-57.

부정민, 강규숙 (2016). 모래놀이치료에서 정점 체험에 대한 현상학적 연구. 상징과 모래놀이 치료, 7(1), 1-30.

서성희 (2013). 우울, 불안, 외현화 경향의 8세 아동의 모래놀이치료 사례연구. 모래놀이치료 연구, 9(1), 1-39.

성은경 (2015). 눈물: 개성화로 이끄는 치유의 상징. 상징과 모래놀이치료, 6(2), 47-60.

소병혜 (2018). 개성화를 위한 영적 안내의 상징으로서의 지팡이. 상징과 모래놀이치료, 9(2), 43-59.

스리자나 타파, 장미경 (2016). 네팔 지진 생존자의 모래놀이치료 과정에서 나타난 힌두 신, 뱀, 요정 이미지. 상징과 모래놀이치료, 7(2), 43-55

신미경 (2011). 불안수준이 높은 모녀의 개별 모래놀이치료사례. 모래놀이치료연구, 7(2), 1-27. 신지환, 장미경 (2016). 집단모래놀이치료가 스마트폰중독 청소년의 중독수준과 우울 및 불 안에 미치는 효과. 상징과 모래놀이치료, 7(1), 31-45.

심희옥 (2011). 모래놀이치료로 여성성을 회복해 가는 이혼가정의 초등학교 5학년 여아에 대한 사례연구. Family and Environment Research, 49(1), 55-65.

심희옥 (2011). 행동규제가 힘든 시설아동이 모래놀이치료를 통해 의식화 되는 과정에 관한 사례연구. 놀이치료연구, 15(3), 101-116.

심희옥 (2012). 선택적 함묵증 여아의 모래놀이치료 사례연구. 兒童學會誌, 33(1), 41-62.

심희옥 (2012). 내재화 및 외현화 행동문제를 보이는 조손가정 남아의 모래놀이치료 사례연 구. 한국아동심리치료학회지, 7(2), 75-96. 
심희옥 (2013). 수동형 공격행동 문제를 보이는 저소득 가정 남아의모래놀이치료 사례연구. 한국아동심리치료학회지, 8(2), 1-22.

심희옥 (2014). 폭력가정에서 성장한 여자 대학생에 대한 부성 콤플렉스 관점에서의 모래놀 이치료 사례연구. 한국가정관리학회지, 32(2), 143-157.

심희옥 (2014). 어머니와 갈등이 심한 남자 중학생의 모래놀이치료 사례연구. 한국가정관리학 회지, 32(6), 1-18.

심희옥 (2014). 학교와 가정에서 부적응 문제를 보이는 저소득 모자가정 초등학생 남아의 모래놀이치료 사례연구. 兒童學會誌, 35(1), 17-41.

심희옥 (2015). 어머니와 오빠의 심한 갈등 속에서 생활하는 초등학생 여아의 모래놀이치료

사례연구. 兒童學會誌, 36(1), 19-45.

심희옥 (2015). 모래놀이치료를 통한 지적장애 남아의 정신세계에 대한 이해. 한국보육학회

학술대회자료집, 2015, 257-258.

심희옥 (2016). 원형탈모증을 않는 6세 여아의 모래놀이치료 사례연구. 한국놀이치료학회지(놀 이치료연구). 19(1), 1-19.

심희옥 (2016). 학업이 힘든 조손가정 남아의 모래놀이치료 사례연구: 연금술적 관점을 중심

으로. 한국놀이치료학회지(놀이치료연구), 19(4), 423-446.

심희옥 (2017). 관계에 어려움이 있는 중년기 여성의 모래놀이치료 사례연구. Family and

Environment Research, 55(3), 303-319.

심희옥 (2018). 가정생활에서 마음이 자유로워지고 싶어하는 부정적인 모성콤플렉스를 지닌

여성의 모래놀이치료 사례연구. Family and Environment Research, 56(4), 331-354. 신유순 (2017). 모래놀이치료에서의 '사슴' 상징에 대한 고찰. 모래놀이치료연구, 13(2), 1-25. 안운경, 곽현정, 김종우, 임명호 (2017). 모래놀이치료가 청소년의 행동, 정서에 미치는 임상

효과 - 다면적 인성검사를 중심으로. 한국콘텐츠학회논문지, 17(12), 257-265.

안은선 (2014). 모래놀이치료에서 정서의 창조적 분출과 정신적 재탄생의 상징으로서의 화

산의 분석심리학적 의미. 상징과 모래놀이치료, 5(2), 77-87.

알렉산더 에스터휘젠 (2014). 모래놀이의 “안전하고 보호된 공간”. 모래놀이치료연구, 10(1), 1-16.

양예슬 (2014). 모래놀이치료가 농촌조손가정아동의 행동문제와 자아존중감 및 정서지능에 미치는 효과. 상징과 모래놀이치료, 5(1), 13-25.

양한연 (2012). 알코올중독자 자녀의 정서적 지지를 위한 모래놀이치료 사례. 모래놀이치료연

구, 8(2), 49-68.

어해룡 (2011). 자해하는 남아의 모래놀이치료 사례연구. 모래놀이치료연구, 7(1), 55-81.

엄미연 (2014). 물: 잠재성의 상징. 상징과 모래놀이치료, 6(1), 59-71. 
Journal of Symbols \& Sandplay Therapy, Vol.11 No.1.

오경임, 김도연 (2017). 우울 청소년에게 적용한 모래놀이치료 사례연구. 발달지원연구, 6(1), 55-67.

오미향, 박성옥 (2014). 집단모래놀이치료가 조현병 환자의 정서표현 및 대인관계에 미치는 영향. 자연과학, $25,145-173$.

오세선 (2013). 커플의 모래놀이치료가 부부관계 증진에 미치는 효과 검증. 모래놀이치료연구,

9(2), 1-29.

오승희 (2011). 모래놀이치료가 재한 중국유학생의 외로움, 불안, 생활 스트레스 및 학교적 응능력에 미치는 효과. 상징과 모래놀이치료, 2(1), 55-75.

오애니아, 유승은, 박부진 (2013). 부모-자녀모래놀이치료가 모-자의 애착안정성과 의사소통

에 미치는 효과. 兒童學會誌, 34(6), 31-55.

옥수정, 노남숙 (2017). 형제모래놀이치료가 $\mathrm{ADHD}$ 아동의 형제관계에 미치는 영향. 한국기

독교상담학회지, 28(3), 85-112.

우희정 (2010). 외상 후 스트레스 장애 증상을 보이는 대학생의 모래놀이치료 사례연구.

Family and Environment Research, 48(3), 55-69.

우희정 (2012). 불안이 내재된 아동의 모래놀이치료사례. 한국부모놀이치료학회지, 3(3), 23-43.

위영희 (2015). 어머니에 대한 증오로 고통 받는 중년 여성의 모래놀이치료 사례연구. 모래

놀이치료연구, 11(2), 88-124.

유미림 (2014). 모성성을 회복하는 30대 직장여성의 모래놀이치료사례 연구. 모래놀이치료연

구, 10(2), 69-98.

유세연 (2016). 맷돌: 대극의 합일과 새로운 의식창조의 상징. 상징과 모래놀이치료, 7(1), 47-64.

유수연 (2015). 모래놀이치료가 알코올중독자 아버지를 둔 아동의 불안과 애착관계 및 대인

관계 스트레스에 미치는 효과. 상징과 모래놀이치료, 6(1), 21-35.

유승은, 박부진 (2010). 집단모래놀이치료가 아동의 불안감소와 자아탄력성 증진에 미치는

영향. 놀이치료연구, 14(1), 67-88.

유승은, 박부진 (2011). 아동의 자아개념형성과 자아발달 촉진을 위한 집단모래놀이치료 효

과. 兒童學會誌, 32(3), 163-184.

유승은, 박부진 (2015). 구조적 가족치료를 활용한 가족모래놀이치료가 정서 행동장애아 가

족의 건강성에 미치는 효과. 한국가정관리학회지, 33(4), 33-50.

윤미이 (2017). 복합외상을 보이는 등교거부 청소년의 자아발달 및 자아정체성 형성과정 모

래놀이치료 사례연구. 모래놀이치료연구, 13(1), 1-37.

윤복남 (2014). 상징‘나비'에 대한 고찰. 모래놀이치료연구, 10(2), 99-115.

이나경 (2015). 개성화를 잉태하고 있는 모성 상징으로서의 산. 상징과 모래놀이치료, 6(1), 
55-68.

이나경 (2016). 촛불: 신성한 보호 공간에서의 의식화의 상징. 상징과 모래놀이치료, 7(2), $73-88$.

이미숙 (2011). 아동의 모래놀이치료에서 주호소별 소품(상징물) 사용 경향. 아동가족치료연구,

9, 54-66

이미숙, 박부진 (2011). 아동의 연령 및 성별에 따른 모래놀이치료 상징물 사용. 놀이치료연

구, 15(1), 29-42.

이미애 (2010). 불안한 청소년의 모래놀이치료 사례. 상징과 모래놀이치료, 1(1), 41-60.

이미애, 서혜전 (2016). 부모로 인한 성노출 피해아동의 모래놀이치료 사례연구. 열린부모교

육연구, 8(2), 91-110.

이미영 (2012). 검: 의식화의 발달. 상징과 모래놀이치료, 3(2), 37-53.

이부연, 장미경 (2015). 북한이탈청소년과 남한청소년의 모래놀이치료에서의 표현 상태 비

교. 상징과 모래놀이치료, 6(2), 31-45.

이부연, 장미경 (2015). 북한이탈청소년과 남한청소년의 모래놀이치료에서의 심리적 주제 및

이야기 표현 비교. 아동복지연구, 13(4), 61-72.

이세화, 장미경 (2019). 말레이시아 거주 로힝야족 난민 아동의 집단모래놀이치료 주제 및

상징연구. 상징과 모래놀이치료, 9(1), 53-90.

이숙영, 김성희 (20013). 기독교상담의 연구 경향성 분석. 상담학연구, 4(2), 295-307.

이승출 (2017). 자아를 탄생시켜가는 유아의 모래 놀이치료 사례 연구. 모래놀이치료연구,

13(2), 1-28.

이승희, 윤호열 (2012). 모래놀이치료가 대학생의 심리적 안녕감에 미치는 영향. 상징과 모래

놀이치료, 3(2), 1-23.

이승희 (2014). 쥐와 고양이: 그림자의 필연적 대극. 상징과 모래놀이치료, 5(2), 33-56.

이승희 (2016). 정체감기반 메타인지모델에 근거한 모래놀이치료 사례연구. 놀이치료연구,

20(3), 93-116.

이애숙 (1986). 유아교육에 관한 학위논문의 동향분석 (1982 1985). 이화여자대학교 대학원

석사학위논문.

이영숙 (2017). 영적 재탄생을 위한 역치의 상징: 죽음. 상징과 모래놀이치료, 8(1), 49-65.

이세화, 장미경 (2018). 말레이시아 거주 로힝야족 난민 아동의 집단모래놀이치료 주제 및

상징연구. 상징과 모래놀이치료, 9(1), 53-70.

이세화, 프라카슈 (2016). 모래놀이치료에 표현된 네팔 아동복지시설 거주 청소년의 지진경

험 이미지. 상징과 모래놀이치료, 7(1), 81-96.

이여름 (2018). 자기인식과 개성화 과정의 첫 단계로서의 거울의 상징성. 상징과 모래놀이치 
Journal of Symbols \& Sandplay Therapy, Vol.11 No.1.

료, 9(1), 39-52.

이여름, 손춘옥 (2017). 중국 연변 거주 조선족 결손가정 청소년의 모래놀이치료 주제 및 상

징연구. 상징과 모래놀이치료, 8(1), 67-80.

이정숙, 장대형 (2015). 모래놀이치료의 효과성에 관한 메타분석. 한국아동심리치료학회지, 10

(1), $1-26$.

이여름, 장미경, 심종희 (2018). 집단모래놀이치료가 중국 거주 조선족 아동의 또래관계 질

과 행동문제에 미치는 효과. 상징과 모래놀이치료, 9(2), 61-80.

이영선 (2016).모래놀이치료로 성년 통과의례를 치른 중년 남성의 사례. 모래놀이치료연구,

1967(2), 1-29.

이영주 (2015). 대상관계이론의 관점으로 본 공격성을 가진 7세 남아의 모래놀이치료 사례

연구. 한국아동심리치료학회지, 10(2), 15-37.

이은희 (2012). 모래놀이치료가저소득층가정아동의사회성에미치는영향: 사례연구중심으로.

한영연구논문, 4, 149-176.

이의철, 김선희 (2011). 모래놀이를 통한 아동의 자아발달단계의 성별차이에 관한 연구. 모래

놀이치료연구, 7(4), 23-56.

이의철 (2016). 복합외상(C-PTSD)을 경험한 청소년의 모래놀이치료 사례연구. 모래놀이치료연

구, 1967(2), 1-26.

이정은, 박지영, 박부진 (2013). 커플모래놀이치료가 대학생의 자아분화와 이성관계만족에

미치는 효과. 한국가정관리학회지, 31(6), 97-112.

이진희, 권미라 (2016). 모래놀이치료가 장애아동 어머니의 불안과 방어기제 유형 변화에 미

치는 효과. 상징과 모래놀이치료, 7(1), 65-80.

이평순, 이명숙 (2011). 초등학교 입학을 앞두고 모성 분리불안을 겪는 6세 유아의 사례연

구. 모래놀이치료연구, 7(3), 67-99.

이평순 (2013). 한국문화에서 나타나는 용의 상징. 모래놀이치료연구, 9(2). 51-65.

이평순 (2014). 학대받은 아동의 모래놀이치료 - 소녀 영웅의 자아강화 사례연구 -. 모래놀이치

료연구, 10(2), 117-142.

이향주 (2017). 모래놀이치료에서의 코끼리 상징에 대한 연구. 모래놀이치료연구, 13(2), 1-19.

이혜란 (2012). 영원한 젊은이에 대한 모래놀이치료 사례연구. 한국놀이치료학회지(놀이치료연

구), 15(3). 391-418.

이현주 (2018). 청소년의 분노 및 감정조절을 위한 미술치료와 모래놀이치료 병행 프로그램

사례연구. 중독과 복지, 2(1), 103-124.

임맹자 (2011). 우울 성향을 보이는 유아의 모래놀이치료 사례연구. 모래놀이치료연구, 7(3), 31-65, 
임예슬 (2016). 뇌전증 진단을 받은 성인 남자대학생의 모래놀이치료 사례연구. 아동가족치료 연구, 14(2), 81-98.

장경희 (2014). 부적응 학생의 자존감 향상을 위한 모래놀이치료. 상담과 지도, 49, 303-322 장난이 (2010). 모래놀이치료가 $\mathrm{ADHD}$ 성향을 가진 대학생의 자아존중감 및 대인관계에 미

치는 효과. 상징과 모래놀이치료, 10(1), 61-82

장미경 (2014). 모래놀이치료에서의 탈의 원형적, 심리학적 상징성. 상징과 모래놀이치료, 5(2), 1-10.

장미경 (2015). 안동하회탈춤놀이에서의 탈의 분석심리학적 의미와 모래놀이치료에서의 탈 상징. 아동복지연구, 13(2), 99-112.

장미경 (2017). 분석심리학적 모래놀이치료. 서울: 학지사.

장미경 (2017). Archetypal Symbolism in the Recovery Process from Natural Disaster: Sandplay

Therapy of Nepal Earthquake Adolescent Survivors. 상징과 모래놀이치료, 8(2), 1-21.

장미경, 최예린, 이세화, 이여름, 조은진 (2019). 모래놀이치료가 우간다 길거리 아동들의 외

상 후 스트레스 증상과 회복탄력성에 미치는 효과. 상징과 모래놀이치료, 10(2), 35-50.

장은경 (2015). 정서조절의 어려움을 가진 남아의 모래놀이치료 사례. 상징과 모래놀이치료, 6(2), $13-30$.

장현숙 (2009). 무기력감으로 방황하는 청소년의 모래놀이치료 사례연구. 지성과 창조, 12 , 197-235.

장현숙 (2009). 불안하고 자신감이 부족한 중년 여성의 자기실현을 위한 모래놀이치료 적용

사례연구. 한국놀이치료학회지(놀이치료연구), 12(1), 79-102.

장현숙 (2012). 모래놀이치료에서의 '거북이'의 상징적 의미에 대한 일 고찰. 모래놀이치료연

구, 8(2), 29-47.

장현숙 (2013). 만화캐릭터에 빠진 소이증 장애아동의 모래놀이치료 사례연구. 한국놀이치료

학회지(놀이치료연구), 16(1), 33-62.

장현숙 (2014). 지나치게 친구에 집착하는 비행청소년의 모래놀이치료 사례연구. 한국놀이치 료학회지(놀이치료연구), 17(1), 95-117.

전애영(2005). 음성틱이 있는 아동의 모래놀이 치료사례. 놀이치료연구 : 한국아동심리재활학회

지, 9(1), 85-102.

전애영 (2009). 모래놀이치료에서 동물상징의 질적 사례 활용. 놀이치료연구, 13(2), 45-66.

전지현 (2018). 애착으로 인해 불안 및 우울의 정서문제를 보이는 아동의 모래놀이치료 사

례 연구. 아동가족치료연구, $16,59-89$.

정다운, 장미경 (2016). 모래놀이치료가 부모와의 분리경험이 있는 중국 조선족 아동의 부모 -자녀 의사소통 변화에 미치는 효과. 상징과 모래놀이치료, 7(2), 29-42. 
Journal of Symbols \& Sandplay Therapy, Vol.11 No.1.

정병호 (2018). 하나님 형상 연구: 융의 자기(The Self)와 융 모래놀이치료를 중심으로. 목회와

상담, 30, 270-304.

정진호 (2012). 국내 모래놀이치료 학위논문의 연구동향 분석 :1992년 2011년까지의 석. 박사

학위논문 중심으로. 백석대학교 사회복지대학원 석사학위 논문.

조창숙, 윤운성 (2016). 유분증 아동의 모래놀이치료 사례연구. 에니어그램연구, 13(1), 49-75.

조혜언, 김현숙 (2014). 틱 장애 아동을 위한 모래놀이치료 연구. 놀이치료연구, 18(2), 91-107.

조혜정 (2009). 인기아에게 집착하는 여아의 모래놀이치료 사례연구. 놀이치료연구, 13(3),

65-81.

조흥식, 정선욱, 김진숙, 권지성 (2015). 질적 연구방법론 - 다섯 가지 접근 -. 서울: 학지사.

조희순 (2009). 모래놀이치료를 통한 아스퍼거 장애유아의 통합교육 사례연구. 유아교육학논

집, 13(6), 455-480.

채성용 (2011). 부정적 부성상을 극복하는 학대피해 아동사례. 모래놀이치료연구, 7(3), 101-

128.

최금례 (2018). 모래놀이치료를 활용한 비블리오드라마의 개인상담 적용 사례연구. 한국기독

교상담학회지, 29(4), 147-174.

치하라마사요 (2011). 모래상자에서 볼 수 있는 심리적 세계의 구조화와 치료적 개입. 모래

놀이치료연구, 7(4), 81-108.

한미현 (2011). 자아발달적 관점에서 본 5세 유아의 모래놀이치료 사례 연구 : 모래놀이의

주제 및 심리적 변환과정을 중심으로. 모래놀이치료연구, 7(1), 1-26.

한미현 (2017). 개구리' 상징에 대한 고찰. 모래놀이치료연구, 13(2), 1-18.

한송희, 김경희 (2016). 모래놀이치료가 장애아동 어머니의 우울과 양육스트레스에 미치는

효과. 상징과 모래놀이치료, 7(2), 57-71.

한유진, 오소정, 김연신 (2015). 예비부부의 개인 및 관계성장을 위한 이마고기법을 활용한

커플모래놀이치료 프로그램 개발 및 효과. 한국아동심리치료학회지, 10(3), 61-86.

한유진, 신진원 (2009). 집단모래놀이치료 프로그램이 학교 부적응 아동의 자아개념 및 자기

표현에 미치는 효과. 社會科學論叢, 29, 123-137.

허미정 (2014). 애착외상으로 인한 정서조절 문제를 가진 아동의 모래놀이치료 사례. 상징과

모래놀이치료, 5(2), 57-76.

홍주연 (1994). 모래상자 놀이치료가 주의력결핍 과잉행동아의 행동변화에 미치는 효과에

관한 연구. 대구대 재활과학대학원 석사학위 논문.

황혜지 (2017). The Effect of Parent Group Sandplay Therapy on the Nepal Earthquake Survivors:

Post-Traumatic Stress Symptoms, Parenting Stress and Psychological Well-Being of Parents as well as Post-Traumatic Stress Symptoms in Children. 상징과 모래놀이치료, 8(2), 57-70. 
안순자·이여름·이세화·장미경 / 국내 모래놀이치료 연구동향(2009-2018)

황혜정 (2019). 아동연구방법론. 서울: 창지사.

Buboltz Jr, W. C., Miller, M., \& Williams, D. J. (1999). Content Analysis of research in the Journal of Counseling Psychology (1973-1998). Journal of Counseling Psychology, 4๔4), 496.

투고일 : 2020. 03. 30

수정일 : 2020. 05. 22 게재확정일 : 2020. 06. 09 